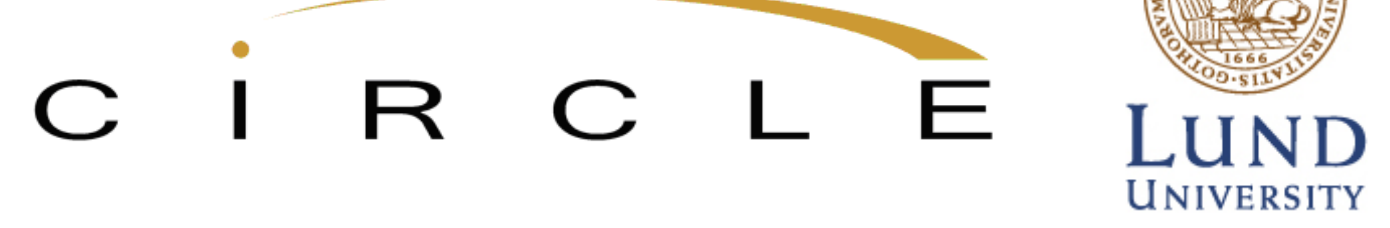

Paper no. 2011/11

\title{
Technological Dynamics and Social Capability: Comparing U.S. States and European Nations
}

\author{
Jan Fagerberg (jan.fagerberg@tik.uio.no) \\ IKE, Aalborg University, TIK, University of Oslo and CIRCLE, Lund \\ University
}

Maryan Feldman (maryann.feldman@unc.edu) University of North Carolina, Chapel Hill

Martin Srholec (Martin.Srholec@circle.lu.se)

CERGE-EI, Charles University and Economics Institute of the Academy of Sciences of the Czech Republic, CIRCLE, Lund University

This is a pre-print version of a paper that has been submitted for publication to a journal

Centre for Innovation, Research and Competence in the Learning Economy (CIRCLE)

Lund University

P.O. Box 117, Sölvegatan 16, S-221 00 Lund, SWEDEN

http://www.circle.lu.se/publications 
WP 2011/11

Technological Dynamics and Social Capability: Comparing U.S. States and European Nations

Jan Fagerberg, Maryan Feldman and Martin Srholec

\section{ABSTRACT}

This paper analyzes factors that shape the technological capabilities of individual U.S. states and European countries, which are arguably comparable policy units. The analysis demonstrates convergence in technological capabilities from 2000 to 2007. The results indicate that social capabilities, such as a highly educated labor force, an egalitarian distribution of income, a participatory democracy and prevalence of public safety, condition the growth of technological capability. The analysis also considers other aspects of territorial dynamics, such as the possible effects of spatial agglomeration, urbanization economies, and differences in industrial specialization and knowledge spillovers from neighboring regions.

Key words: innovation, technological capabilities, European Union, United States

Disclaimer: All the opinions expressed in this paper are the responsibility of the individual author or authors and do not necessarily represent the views of other CIRCLE researchers. 


\title{
Technological Dynamics and Social Capability: Comparing U.S. States and European Nations*
}

\author{
Jan Fagerberg*, Maryann Feldman** and Martin Srholec*** \\ *) IKE, Aalborg University, TIK, University of Oslo and CIRCLE, Lund University \\ **) University of North Carolina, Chapel Hill \\ ***) CERGE-EI, Charles University and Economics Institute of the Academy of Sciences of the \\ Czech Republic, CIRCLE, Lund University
}

Version of December 5, 2011

\begin{abstract}
This paper analyzes factors that shape the technological capabilities of individual U.S. states and European countries, which are arguably comparable policy units. The analysis demonstrates convergence in technological capabilities from 2000 to 2007. The results indicate that social capabilities, such as a highly educated labor force, an egalitarian distribution of income, a participatory democracy and prevalence of public safety, condition the growth of technological capability. The analysis also considers other aspects of territorial dynamics, such as the possible effects of spatial agglomeration, urbanization economies, and differences in industrial specialization and knowledge spillovers from neighboring regions.
\end{abstract}

Key words: innovation, technological capabilities, European Union, United States

JEL codes: R11, R12, O32, O33

\footnotetext{
*Work on this paper started in 2008 when the authors worked together in the "Understanding Innovation Group" at the Center for Advanced Studies (CAS) in Oslo and the support from the Center is gratefully acknowledged. Martin Srholec also wants to thank the Czech Science Foundation (GAČR) for financial support (project P402/10/2310). Feldman would like to acknowledge support from the U.S. National Science Foundation SciSIP 0947814.
} 


\section{Introduction}

When trying to explain, and possibly influence, long run economic growth, attention has increasingly turned to the social, institutional and economic factors that affect technology and productivity growth. Examples include Porter's four-factor diamond model in his The Competitive Advantage of Nations (1990); the literature on national and regional "systems of innovation" (Lundvall 1992, Nelson 1993, Braczyk et al. 1998); and notions such as social capital (Putnam 1993) or social filter (Crescenzi et al. 2007). The policy implication is that to successfully generate adequate technological capabilities and exploit these economically, a number of supporting social, institutional and economic factors need to be in place.

In contrast to this broad perspective on what matters for growth, the so-called "new growth theory" (Romer 1990, Aghion and Howitt 1992) attributes cross-country differences in income and productivity to a single factor only - the ability to devote resources to research and development $(\mathrm{R} \& D)$. The message that increasing $R \& D$ was the right direction for policy was received with enthusiasm by governments in Europe, who in the so-called 'Lisbon Strategy'adopted by EU around the turn of the millennium - stated that R\&D investment should increase to three percent of GDP within a decade, up from the prevailing rate of less than two percent, with the purpose of making Europe "the most competitive and dynamic knowledge-based economy in the world, capable of sustainable economic growth with more and better jobs and greater social cohesion."1 The adoption of this goal was influenced by the observation that the United States, commonly seen as Europe's main global competitor, had a share of R\&D to GDP far above the European level. In the United States, conversely, fears of falling behind have created a call for policies to subsidize private sector investments in $R \& D$ and for increased government R\&D spending.

In our view, an important shortcoming of the prevailing analysis underlying the Lisbon Strategy and other policy discussions is a far too narrow focus on what shapes technological dynamics. The sole focus on $\mathrm{R} \& \mathrm{D}$, while perhaps consistent with new growth theory, overlooks that R\&D—while important — is only one among several factors influencing technological competitiveness (Fagerberg et al. 2004). Not all innovation results from or requires R\&D, and a

${ }^{1}$ Lisbon European $\quad$ Council 23-24.03.2000:
(http://www.europarl.europa.eu/summits/lis1_en.htm) 
high level of R\&D spending does not translate directly to innovation. To succeed in innovation, supporting resources and institutions are necessary, extending beyond the single firm to the wider environment in which the firm is embedded (Feldman and Kogler 2010). A proper analysis of technological growth therefore requires a perspective that takes these wider aspects into account.

Another problem is that much of the prevailing analyses are based on comparisons between variable means for very large and heterogeneous geographical entities. Hence, the great variation within Europe and the US tends to be overlooked, and this has implications for the analysis of the technological dynamics of the two continents (Crescenzi et al. 2007). Sweden, for example, invests nearly four percent of its GDP in R\&D, which is about the same as California or Massachusetts. However, this investment is almost ten times that of several EU countries, such as Greece, Slovakia or Romania, or U.S. states, such as Wyoming or South Dakota. Moreover, the finding that some parts of Europe compare well with the most advanced regions of the US also holds when considering other social and economic data (King 2004). Thus, it seems pertinent to take such spatial heterogeneity into account when analyzing the technological dynamics of, say, Europe and the US and advocating for policy interventions. Responding to this need, this paper analyzes technological dynamics in the two continents using the same indicators for European countries and US states. Arguably, states are more comparable to European countries than the US as whole due to the heterogeneity within the U.S.

The only prior attempt to tackle this issue, by Crescenzi et al. (2007), compares US cities to EU regions for the period of 1990-2002. To measure the outcome of the territorial dynamics of innovation, they use patent counts as their dependent variable. However, patents do not really measure innovation. Patenting is much more widely used in some technological fields (e.g., chemicals, biotechnology) than in others (Smith 2004). Many inventions protected by patents never make it to the market, while many, if not most, innovations introduced to the market are not patented. Thus, although patents provide useful information on certain aspects of technological activity, this paper applies a broader perspective. Moreover, while Crescenzi et al. (2007) find that there are important differences in the technological and territorial dynamics between the two continents, their conclusions are based on separate analyses that do not always employ the same or comparable variables. Arguably, robust conclusions about the difference in 
technological dynamics require a common framework for comparison-i.e., the same model and variables.

The next section outlines a synthetic framework for analyzing technological dynamics that takes into account key insights from innovation theory (Kline and Rosenberg 1986, Fagerberg et al. 2004), development studies (Adelman and Morris 1965, Kim 1980, 1997, Lall 1992), economic history (Abramowitz 1986), and economic geography (Feldman and Kogler 2010). The literature suggests a broader notion of technological capability as the central variable and the inclusion of a set of social capabilities as conditioning variables for the development of technological capability. The analysis also takes into account territorial dynamics, such as the possible effects of spatial agglomeration, urbanization economies, differences in industrial specialization, and knowledge spillovers from neighboring regions. Section 3 presents the 75 geographical entities (48 states in the continental US and 27 countries in Europe) that form the basis of the paper and considers how capabilities may be measured empirically. Factor analysis is used to give a concise representation of how technological and social capabilities differ across US states and European countries. In section 4 we present the results of our econometric estimation and compare the conclusions reached in this paper with those of previous research. Finally, section 5 concludes with a focus on what can be learned about what shapes technological dynamics in the US and Europe and what the policy implications may be.

\section{Technological dynamics: A synthetic framework}

Technology may be defined as knowledge about how to produce goods and services. Most people today would probably accept the view that technology and economic performance are intimately related. However, from the classical political economists onwards, the field of economics has viewed growth and development as mainly arising from the accumulation of capital (through the introduction of new machinery). The tendency to reduce technology to machinery, or knowledge to artifacts, was widespread. Even a highly heterodox economist such as Veblen (1915) — who was the first to analyze technological catch-up processes in the world economy - argued along these lines. According to Veblen, in contrast to conditions that had

prevailed previously, the "machine technology" "can be held and transmitted ... and the 
acquisition of it by such transfer is no laborious or uncertain matter" (ibid 191). In short, because of the easy transfer of technology, catch-up should be expected to be easy.

Most neoclassical economists in the early post-war period shared this optimistic mood, and expected that technology diffusion would lead to widespread economic growth. According to Robert Solow, the most famous contributor to the development of the neoclassical theory of economic growth, technology_or knowledge_-should be regarded as a public good freely available to anybody with a desire to share it, independent of his or her background or location (Solow 1956). It follows that technology should be expected to benefit everybody to the same extent-an assumption adopted in subsequent applied research based on the neoclassical perspective. For example, Denison, the leading researcher of cross country economic growth differences in the early post war period, put it as follows: "Because knowledge is an international commodity, I should expect the contribution of advances of knowledge (...) to be of about the same size in all the countries..." (Denison 1967, p. 282).

As is well known, these optimistic predictions were not confirmed by historical evidence. In fact, the disparities in development in the global economy are far greater today than before the industrial revolution (Landes 1998). Thus, the potential for diffusion to catch up across borders appears to be difficult. This was also the conclusion that Denison arrived at after consulting the evidence: "On the surface, to reduce the gap greatly would not seem very difficult ... In contrast ... the historical record ... suggests that either the desire is lacking or imitation is a very difficult thing." (Denison 1967, p. 340). Such findings have been confirmed by subsequent research (Fagerberg1994, Fagerberg and Srholec 2005).

This points to the need for a more realistic understanding of the factors that condition knowledge creation and affect its diffusion in space than has characterized theoretical and applied work in economics. A worldwide stock of homogenous knowledge, capable of flowing across the globe at the speed of light and being exploited by anyone as much as he or she likes, does not exist. Rather, there are many different types of knowledge and knowledge holders. In fact, already Nobel laureate Friedrich von Hayek (1945) pointed out that it is impossible for any actor, being a person or a firm (or a government for that matter), to know have the "perfect knowledge" relevant for the solution of an economic problem. Just to identify what the relevant areas of knowledge are may in fact be quite challenging. Moreover, as Hayek repeatedly stressed, not all knowledge is scientific. Much of knowledge is practical, personal and context- 
specific (Polanyi 1958, 1966). To successfully access and gainfully use such knowledge, intimate familiarity with its context may be required. This is one important reason why geographic proximity may be important for realizing the benefits of knowledge flows (Jaffe, Trajtenberg and Henderson 1993; Audretsch and Feldman 1996).

Even in cases where relevant knowledge is identifiable, codified and easily accessible, there is no guarantee that it will be successfully transferred. Knowledge may, for example, be difficult to understand and absorb. Higher education at the doctorate level may be required to gain the capabilities needed to understand, absorb and exploit detailed scientific knowledge (Cohen and Levinthal 1990). Building such capabilities may be demanding, costly and timeconsuming, for an individual, firm or society. In addition, innovative firms cannot rely on only one type of knowledge. They need to be able to access, absorb, combine and use many different types, related to, for example, finance, logistics, products, markets, and production. Access to necessary resources, such as Information and Communication Technologies, means of transport and skilled labor, and knowledge about how to maintain and exploit these resources, is also crucial. It is of little help to be aware of some promising knowledge if you lack the resources necessary to reap benefits from its exploitation.

A commonly used term for the ability of a firm to acquire, hold and utilize knowledge is “technological capability" — coined by the Korean development economist Linsu Kim (1980, 1997), who defined it as "the ability to make effective use of technological knowledge in efforts to assimilate, use, adapt and change existing technologies, .... to create new technologies and to develop new products and processes ..." (Kim 1997, p. 4). Using the example of Korean electronics firms, Kim further distinguished between different layers of technological capability depending of the complexity of the challenge. He identified production capability, which is required to operate production efficiently; investment capability, required to enter into lines of business new to the firm (though not necessarily to the world); and finally, innovation capability, which is needed if the firm wishes to change or develop entirely new products or processes. Kim expected the requirements with respect to innovation capabilities, to become more stringent as the distance to the technology frontier becomes smaller.

Although initially developed for the analysis of firms, the technology capability concept may also be applied to networks, industries or countries. Indeed, a central insight from the literature on innovation is that a firm's technological capabilities do not depend solely on its own 
activities but also the capabilities of its customers, suppliers and other firms and organizations with which the firm interacts (Lundvall 1992, Nelson 1993, Edquist 2004). Lall (1992), in a survey of the literature on technological capabilities, emphasized three aspects of "national technological capability:" the ability to muster the necessary (financial) resources and use them efficiently; skills, including not only general education but also specialized managerial and technical competence; and a "national technological effort", which he associated with measures such as R\&D, patents and technical personnel. Lall also pointed to the incentives that economic agents face, whether resulting from political decision making (e.g., governance) or embedded in more long-lasting institutions (the legal framework for example), are important for the development of technological capabilities and their economic effects.

It is not a wholly new insight that the ability of a firm to generate and benefit from technological capabilities also depends on the social, institutional and political characteristics of the environment in which it is embedded. In fact, in the 1960s Adelman and Morris (1965, p. 578) pointed out, based on an in-depth study of a number of indicators on development for a large number of countries, that "the purely economic performance of a community is strongly conditioned by the social and political setting in which economic activity takes place. Abramowitz (1986) described these characteristics as representing "social capability", which he defined as "countries' levels of general education and technical competence, the commercial, industrial and financial institutions that bear on the abilities to finance and operate modern, large-scale business, and the political and social characteristics that influence the risks, the incentives and the personal rewards of economic activity" (Abramovitz 1994, p. 25). Putnam (1993, p. 167,) and other writers on "social capital" also point to the importance of "features of social organization, such as trust, norms and networks, that can improve the efficiency of society by facilitating coordinated actions" (see also Woolcock and Narayan 2000). ${ }^{2}$ Hence, there is no lack of literature emphasizing the importance of social factors in knowledge diffusion. The problem is rather how to exploit these insights in empirical research. This is one of the topics to be explored in the next section.

\footnotetext{
${ }^{2}$ In sociology the term social capital is often used as an attribute of individuals, not as a characteristic of communities, as in the tradition from Putnam. For an overview and discussion of different usages of the term see Portes (1998).
} 
How countries or regions fare when it comes to developing and sustaining technological capabilities may also depend on more specific territorial characteristics. It has, for instance, been argued that larger and more densely populated regions are at advantage in this respect because of their larger markets for knowledge-intensive services and lower transaction costs, which allow for a richer set of capabilities to develop (Jacobs 1969, Bairoch 1988, Feldman 1994). Moreover, as mentioned above, proximity to other knowledge hubs may condition the extent to which capability development is enhanced by the activity of other actors located nearby (Feldman and Kogler 2010). Industrial structure may also influence the absorption of knowledge; specifically, industrial specialization may allow for greater exploitation of economies of scale and a deepening of technological capabilities due to the benefits of localization economies (Iammarino and McCain 2006). However, a highly specialized economy may also reduce the ability to absorb knowledge by limiting the scope of discovery and diversity of capabilities (Feldman and Audretsch 1999). Another means to diffuse knowledge is the migration of skilled personnel (Henderson 2010).

In summary, technological capability is a broad phenomenon that cannot be reduced to a single indicator, such as, for example, patents or R\&D. A broader perspective is clearly needed and the next section considers this in more detail. Moreover, although diffusion of technology is challenging, it would be a mistake to conclude that a region on country cannot learn from regions with more developed capabilities. On the contrary, as emphasized by economic historians (Gerschenkron 1962, Abramovitz 1986, Landes 1998), a technologically lagging region may benefit greatly by exploiting such technology gaps to its advantage. But success in doing so depends on characteristics at the receiving end, i.e., its capabilities, or in the words of Moses Abramovitz: "a country's potential for rapid growth is strong not when it is backward without clarification, but rather when it is technologically backward but socially advanced"(Abramovitz 1986, p. 388). Thus, technological dynamics - including the ability to learn from others - are conditioned by wider social, institutional and economic factors, which hence need to be taken into account. 


\section{Measuring capabilities in Europe and the US}

Rather than taking into account the rich variation within the U.S. and Europe, current analyses often rely on mean values, ignoring the reality that territorial sub-units have autonomy in defining policies that influence technological dynamics, as well as differing social, institutional and economic characteristics. In contrast, this paper uses U.S. states and European countries as units of observation. ${ }^{3}$ One challenge was finding comparable data relevant for the measurement of technological and social capabilities. The data set consists of observations for 48 US states and 27 European countries between 2000, the year the Lisbon Strategy was adopted, and $2007 .^{4}$

Technological capabilities are partly firm-level and partly characteristics of the external environments that firms share (and draw on for their technological activities). Indicators such as business $R \& D$, patenting, etc. refer to the former, while university $R \& D, P h D s$ in science and engineering, scientific publications in science and engineering pertain to the latter. Alternatively, these indicators may be termed innovation capabilities. Another aspect of technological capability is so called investment capabilities, e.g. the ability to finance for new, technologically advanced initiatives, for which venture capital may be a good indicator. A third aspect refers to production capabilities, which-although less advanced than the ones mentioned above-are often considered to be of great importance in developing country environments. Examples of relevant indicators include access to ICT and adherence to standards. Unfortunately, such indicators were not available for the present study. However, since the countries and states included here are advanced compared to the developing world, and hence probably would have excelled on these indicators, the lack of this dimension here may not be very important in practice.

\footnotetext{
${ }^{3}$ Countries/regions not connected to the rest of continent were excluded (Hawaii and Alaska in the US, Iceland, Malta and Cyprus in Europe). In addition, in the US, the District of Columbia (home to the capital of the country) was excluded, because there is not a natural counterpart in Europe.

${ }^{4}$ See Appendix A1 for additional detail.
} 
Table 1: Technological capability: Descriptive statistics

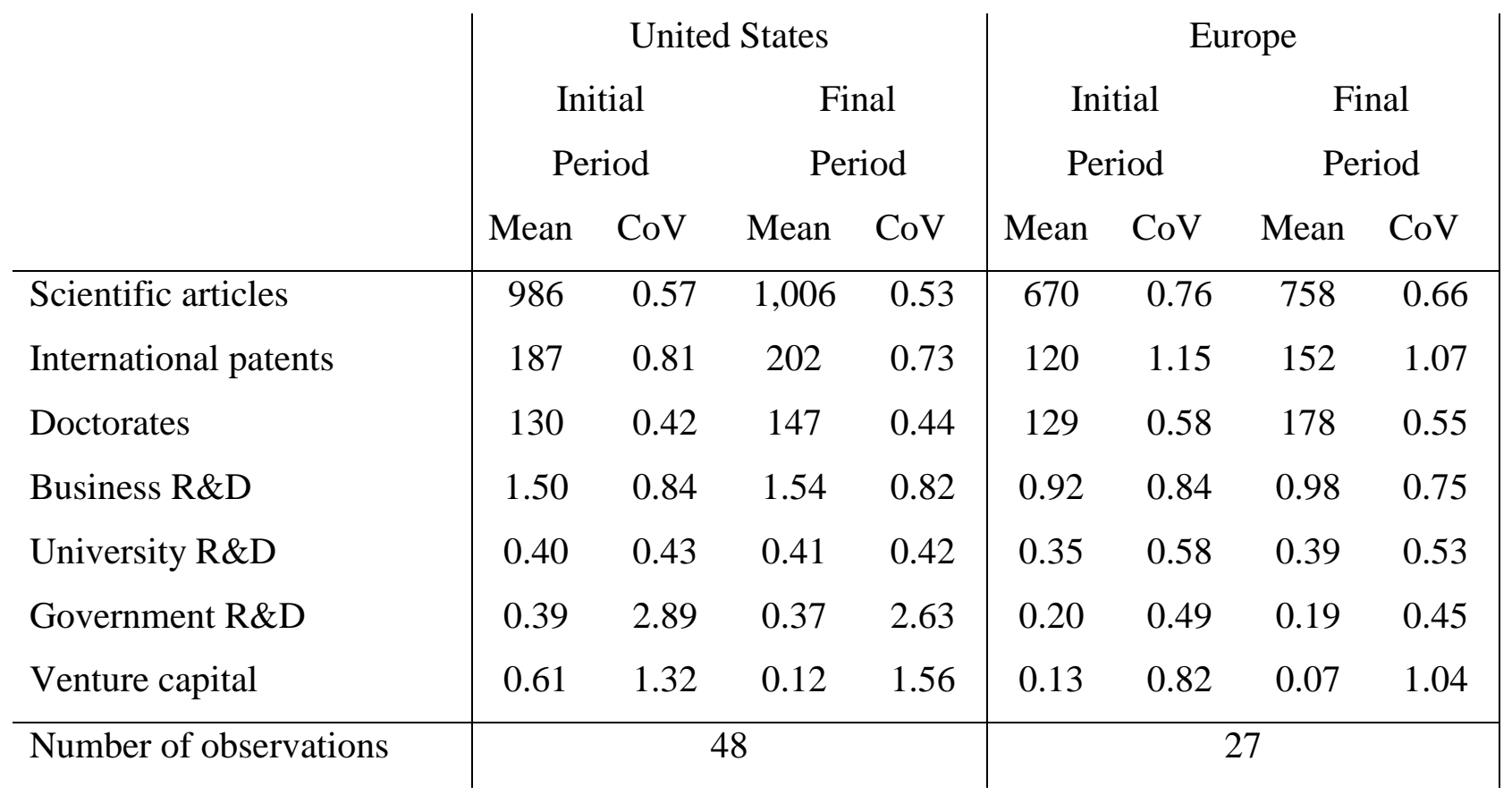

Note: $\mathrm{CoV}$ is the coefficient of variation. For GOVRD and UNIRD the initial period is 2002, i.e. not 2000, due to a break in time series in data for the US states.

Source: See Appendix A1.

Table 1 contains descriptive statistics for these indicators (means and coefficients of variation) for the US and Europe, while sources are provided in Appendix Table A.1. The US is ahead of Europe on most indicators, including business R\&D, international patents, and venture capital. It also leads in scientific publishing, but to some extent this may reflect that the US is home to the majority of English-language journals. For University R\&D Europe is approximately equivalent to the US. The only indicator for which Europe clearly outperforms the US is new $\mathrm{PhDs}$ in science and engineering, after having been relatively equivalent a decade ago. Government R\&D appears to be a special case: the U.S. level doubles that of Europe, and the coefficients of variation are also notably higher. This reflects the importance of defense R\&D in the US, which tends to be located in remote places away from other research environments, possibly to minimize spillovers, which in this case may be seen as a possible security risk or alternatively to provide a boost to lagging states. 
Table 2: Technological capability: Results of the factors analysis

\begin{tabular}{l|c}
\hline & $\begin{array}{c}\text { Technological } \\
\text { capability } \\
\text { TECH }\end{array}$ \\
\hline Scientific articles & 0.93 \\
International patents & 0.89 \\
Doctorates & 0.75 \\
Business R\&D & 0.83 \\
University R\&D & 0.69 \\
Government R\&D & 0.09 \\
Venture capital & 0.66 \\
\hline Number of observations & 150
\end{tabular}

Note: The extraction method is principal component factors; based on pooled data for 75 observations from the initial and final period (150 observations in total).

Source: See Appendix A1.

Next, we conducted a factor analysis of the eight indicators of technological capabilities for the two periods to examine to what extent these can usefully be aggregated into one or more common factors. To limit the influence of outliers, all variables are in logs. As is shown in Table 2, only one principal factor, explaining $54.7 \%$ of the total variance, emerges from the analysis. This factor, which we label "Technological Capability", is strongly correlated with the other indicators, with the sole exception of Government R\&D, which is not significantly correlated with any other indicator. ${ }^{5}$ The resulting factor score of the "Technological Capability" variable was normalized to a 0-100 range, with zero for the least advanced and one hundred for the most advanced region:

$$
100 *\left(\frac{\mathrm{TECH}_{\mathrm{i}}-\min (\mathrm{TECH})}{\max (\mathrm{TECH})-\min (\mathrm{TECH})}\right)
$$

\footnotetext{
${ }^{5}$ Indicators that do not fit into the overall pattern should in principle be eliminated because they may bias the results. If government $\mathrm{R} \& \mathrm{D}$ is eliminated, the proportion of variance explained by the single principal factor increases to $63.8 \%$. But is has only a negligible effect on the factor score, which is $99 \%$ correlated with the one reported here.
} 
Table 3: Technological capability, final period

US states

EU/EFTA countries

Top 10

Top 10

Massachusetts $\quad 100$

Sweden $\quad 86$

Maryland 82

Switzerland 83

California $\quad 78$

Finland 81

Connecticut $\quad 76$

Denmark 73

Washington 75

United Kingdom 71

New Hampshire 73

Netherlands $\quad 70$

Minnesota 72

Norway 69

Pennsylvania 72

Germany 67

Colorado 71

Austria 66

Rhode Island 69

Belgium 64

Average $\quad 60$

Average $\quad 51$

Median 60

Median 54

Coefficient of variation $\quad 0.23$

Coefficient of variation $\quad 0.44$

Bottom 10

Bottom 10

Kentucky $\quad 48$

Estonia 44

West Virginia 45

Luxembourg 43

Wyoming 44

Hungary 35

Oklahoma 43

Greece 34

Maine 42

Lithuania 27

Louisiana 42

Poland 27

Mississippi 41

Slovakia 26

South Dakota 38

Latvia 14

Nevada 34

Romania 12

Arkansas 31

Bulgaria 6

Source: See Appendix A1. 
Table 3 reports the estimated levels of technological capability for the top and bottom ends of the distribution for the US and Europe. Since the number of geographical units in the US is about twice that of Europe, the top quintile contains 10 states in the US and 5 countries Europe. Comparing these two groups to each other leads to a very clear result: there are not any significant differences between the top performers in the two continents. In fact, the top five performers of the two continents combined include two US states, Massachusetts and Maryland, and three European countries, Sweden, Switzerland and Finland. This differs markedly for the bottom end of the distribution. Six countries, which are all former Socialist economies in Eastern Europe, have lower technological capabilities than the least sophisticated US state. Omitting these six countries from the calculation of the mean level of technological capability in Europe gives a result that is almost identical to that of the US. Hence, if we focus on Western Europe, then the much-discussed difference in technological capability vis-à-vis the US more or less vanishes.

To get a better impression of the technological dynamics, Figure 1 plots the initial level of Technological capability (TECH) on the vertical axis against the change of this variable $\left(\mathrm{TECH}_{1}-\mathrm{TECH}_{0}\right)$ on the horizontal axis, forming quadrants. The top left quadrant consists of initially advanced regions that grow slowly, if at all, while the bottom right quadrant contains initially lagging regions that are catching up technologically. The great majority of the observations fall into these two quadrants, indicating that there has been a fair amount of technological convergence during the period covered by the investigation. The catching-up group consists of a number of European countries, including some former Socialist countries (the Baltic Countries, the Czech Republic, Slovakia, Slovenia, Romania and Bulgaria), but also some US states, such as North and South Dakota and Wyoming. 
Figure 1: The TECH factor score on Technological Capacity

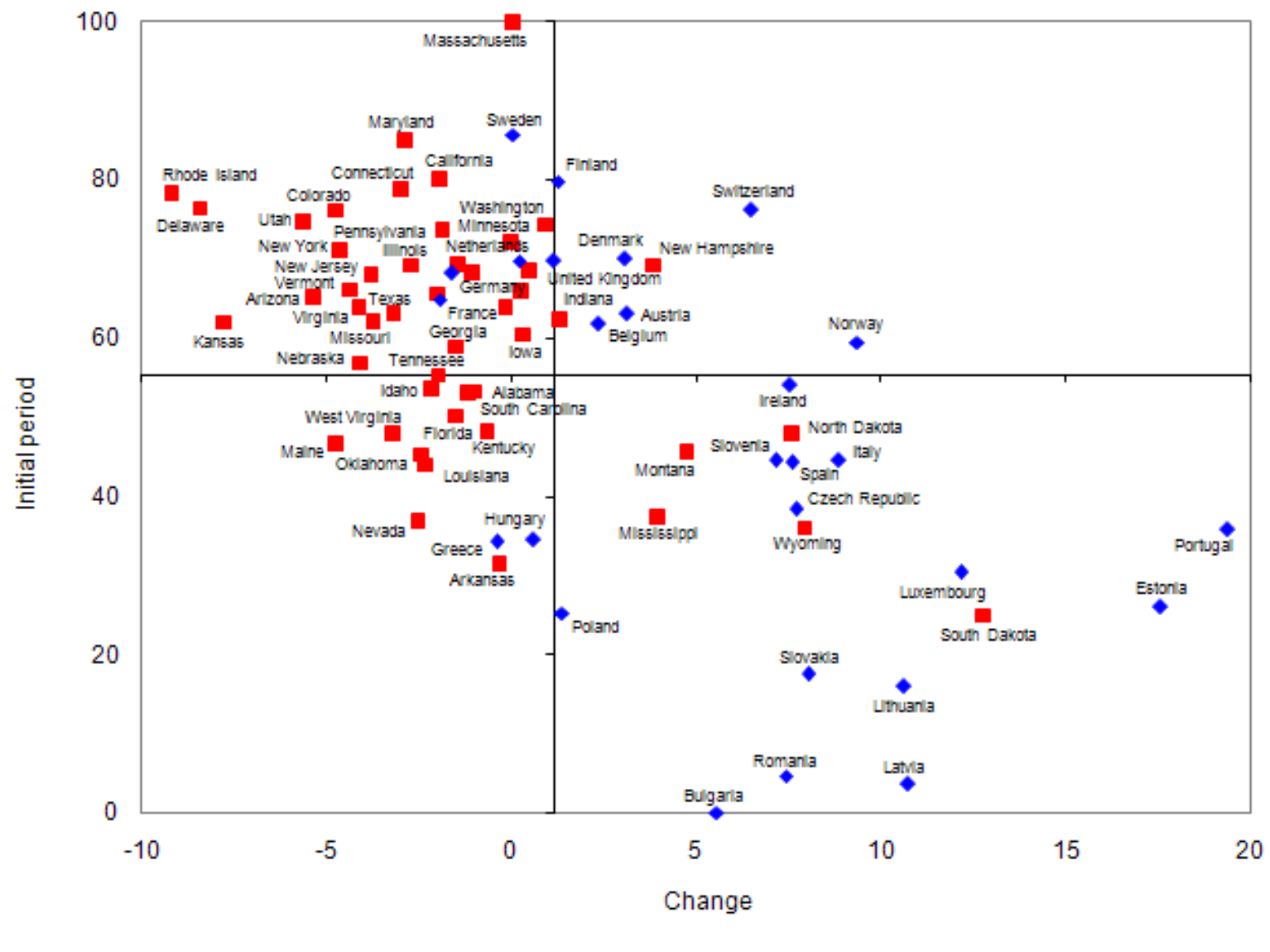

$\bullet$ European countries

UU.S. states

Although the main trend points towards convergence, there are also in the bottom left quadrant a number of initially lagging regions, mostly American states, with below average performance. These risk falling behind, to use Abramowitz's terminology (Abramovitz 1986). ${ }^{6}$ Finally there are in the top right quadrant a small number of advanced regions, mostly European, that continue to pull ahead, among which Switzerland and Norway are the two most obvious examples.

\footnotetext{
${ }^{6}$ It is interesting in light of recent economic developments to observe that Greece is the clearest example in Europe of an initially lagging country that is also "falling behind" technologically. The other European countries that risk being dragged into the present macro-economic crisis, such as Ireland, Portugal, Spain, appear to have a different dynamics.
} 
Next, we searched for data on what Abramovitz (19861) called social capabilities. Following the literature, three aspects may be distinguished: the skill-level of the labor force; how well governance works (particularly with respect to economic activity); and the prevalence of norms, values and institutions that support economic activities and the functioning of society more generally. Relatively good statistics existed on the supply of well-educated personnel and the quality of the educational system (as reflected by teacher-pupil ratios). However, reliable and relevant indicators on governance that covered both US states and European countries were difficult to find. For example, many of the data sources that Fagerberg and Srholec (2008) use to explore these aspects do not exist for sub-national entities. Nevertheless, we chose to consider information on the ability of the government to engage the population in economic activities (unemployment and labor force participation). With respect to the broader social characteristics emphasized by Abramovitz and others, we were able to include information on election turnout, a commonly used indicator of civic activity and, hence, social capital; income inequality; and the frequency of homicides. The latter reflects the importance of public safety in civic society. However, as shown in Appendix Table 2, the frequency of homicides is also strongly correlated with a number of other relevant indicators, such as willingness to take part in civic activities, satisfaction with how society is governed and indicators of law and order at the country level . Hence, we regard the frequency of homicides as an indicator of broader social characteristics as well.

Table 4 contains descriptive statistics on the indicators of social capability. It appears that on average there are no large differences between the two continents with respect to the supply of skilled personnel and the quality of the educational system. There are, however, marked differences along the other dimensions included here, particularly inequality and homicide rates, which are more pronounced in the US, and unemployment, which appears to be a larger problem in Europe. 
Table 4: Social capabilities: Descriptive statistics

\begin{tabular}{l|cc|cc} 
& \multicolumn{2}{|c|}{ United States } & \multicolumn{2}{|c}{ Europe } \\
& Mean & CoV & Mean & CoV \\
\hline Labor force with tertiary education (\% of labor force) & 22.35 & 0.19 & 21.16 & 0.34 \\
Professional and associated jobs (\% total jobs) & 30.70 & 0.10 & 34.51 & 0.17 \\
Teacher-pupil ratio in public schools in elementary and & & & & \\
secondary education & 0.07 & 0.13 & 0.08 & 0.18 \\
Income inequality (quintile share ratio) & 6.65 & 0.12 & 4.31 & 0.22 \\
Election turnout (\% of voting-age population) & 52.87 & 0.13 & 69.32 & 0.17 \\
Homicides (per million adults) & 59.42 & 0.55 & 33.33 & 1.07 \\
Unemployment (\% of labor force) & 3.83 & 0.23 & 8.44 & 0.57 \\
Labor force participation (\% of working age population) & 78.31 & 0.05 & 69.81 & 0.08 \\
\hline Number of observations & \multicolumn{2}{|c|}{48} & &
\end{tabular}

Note: $\mathrm{CoV}$ is the coefficient of variation.

Source: See Appendix A1.

Table 5 reports the results of a factor analysis on the social capability data set for the initial year (some of the indicators are not available for the recent years). As in the previous case, the indicators are entered in logarithmic forms. Three principal factors with eigenvalues higher than one, explaining $78.2 \%$ of the total variance, were detected. First, there is a factor that loads highly on tertiary education and the share of professionals in the labor force and is hence labeled Educated Labor. Second, there is a factor score that combines the various social characteristics, which we label as Social Cohesion. This factor loads positively on election turnout and the quality of the public school system and negatively on income inequality and the rate of homicides. The correlation is particularly high with the rate of homicides, which arguably reflects the strong relationship between this indicator and other relevant social characteristics (see Table A2 in Appendix). Finally, there is a third principal factor that loads negatively on unemployment and positively on participation in the labor force, labeled Labor Market. 
Table 5: Results of the factors analysis on the indicators of social capability

\begin{tabular}{l|ccc}
\hline & Educated & Social & Labor \\
& Labor & Cohesion & Market \\
& EDU & SOC & MKT \\
\hline Labor force with tertiary education & 0.82 & -0.11 & 0.30 \\
Professional and associated jobs & 0.89 & 0.15 & -0.16 \\
Teacher-pupil ratio in public schools & -0.17 & 0.72 & -0.04 \\
Income inequality & -0.16 & -0.74 & 0.30 \\
Election turnout & 0.17 & 0.82 & -0.16 \\
Homicides & 0.05 & -0.91 & -0.30 \\
Unemployment & 0.05 & -0.10 & -0.96 \\
Labor force participation & 0.19 & -0.17 & 0.82 \\
\hline Number of observations & & 75 &
\end{tabular}

Note: The extraction method is principal component factors; oblimin oblique rotation; based on data from the initial period.

Source: See Appendix A1.

Table 6 provides information on the estimated levels of the three measures of social capability for the top and bottom ends of the distribution for the US and Europe. The top five performers in Educated Labor are all European. Only two US states, Massachusetts and Maryland, make it to the top ten. There is less difference towards the end of the distribution, however. For example, the bottom ten performers contain 6 US states and 4 European countries. In the case of Social Cohesion the difference between the US and Europe is much larger. In fact, no US state makes it to the top ten and around one half of them have levels of Social Cohesion below that of the socially least advanced country in Europe. Thus, European countries and US states are not in the same category when it comes to economically important social characteristics. This also holds for the Labor Market factor, but in this case it is the US states that are far ahead of European countries. In fact, no European country makes it to the top ten performers on this dimension, and the great majority has values below that of the worst performing US state. These results are consistent with the well-known US-Europe employment gap that proliferated during the 1980s and 1990s (Gregory, et al. 2007). 
Table 6a: Educated Labor (EDU), initial period

US states

EU/EFTA countries

Top 10

Top 10

Massachusetts

84

Finland

100

Maryland

83

Sweden

92

Connecticut

78

Norway

91

Washington

76

Netherlands

Colorado

74

Minnesota

73

United Kingdom

86

New York

71

Estonia

83

Virginia

70

Belgium

83

New Hampshire

70

Denmark

82

New Jersey

Germany

80

Switzerland

79

Average

60

Average

65

Median

61

Median

67

Coefficient of variation

0.19

Coefficient of variation

0.35

Bottom 10

Bottom 10

Alabama

51

Spain

South Carolina

Czech Republic

Louisiana

Hungary

52

Tennessee

Indiana

Mississippi

Kentucky

42

West Virginia

38

Poland

49

Arkansas

37

Nevada

29

Slovakia

Austria

46

Greece

45

Italy

39

Romania

30

Portugal

0

Source: See Appendix A1. 
Table 6b: Social Cohesion (SOC), initial period

US states

EU/EFTA countries

Top 10

Top 10

North Dakota

65

Luxembourg

100

Maine

61

Denmark

South Dakota

60

Austria

Vermont

Norway

Iowa

Wyoming

49

New Hampshire

49

Wisconsin

Montana

Minnesota

Hungary

Italy

Sweden

Belgium

80

Slovenia

74

Germany

70

Average

Average

64

Median

Median

Coefficient of variation

Coefficient of variation

0.31

Bottom 10

Maryland

New Mexico

Tennessee

Texas

Georgia

13

Mississippi

13

Florida

Nevada

California

Arizona

Source: See Appendix A1.
Bottom 10

Romania 56

Bulgaria $\quad 55$

Finland 53

Czech Republic 52

Ireland 51

Poland 43

United Kingdom 38

Latvia $\quad 37$

Lithuania 30

Estonia 28 
Table 6c. Labor Market (MKT), initial period

US states

EU/EFTA countries

Top 10

Top 10

South Dakota 100

Switzerland 84

North Dakota

Norway

76

Connecticut

94

Portugal

68

Iowa

91

Netherlands

64

New Hampshire

91

Denmark

62

Vermont

89

United Kingdom

59

Massachusetts

86

Austria

58

Nebraska

86

Luxembourg

58

Virginia

86

Colorado

85

Sweden

54

Ireland

52

Average 72

Average

38

Median

71

Median

33

Coefficient of variation

0.17

Coefficient of variation

0.61

Bottom 10

Arizona

Kentucky

Arkansas

California

New York

Alabama

New Mexico

Mississippi

West Virginia

Louisiana

Source: See Appendix A1.
64

62

61

61

60

57

54

52

48

44
Bottom 10

Czech Republic

Greece

Estonia

Hungary

Lithuania

Italy

Poland

Latvia

Slovakia

Bulgaria

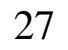

20

18

14

12

11

10

6

7

8

12

0 
The analysis of technological and social capabilities in the US and Europe shows that there are marked differences both within and across the two continents in the various aspects taken into account here. It is not obvious from looking at these data that there exists a typical US state or - alternatively - a typical European country. As pointed out in the introduction to this paper, typologies consistent with the data may just as well cut across the two continents. To explore this question further, we carry out a cluster analysis of the geographical units included in our analysis based on their initial technological and social capabilities (TECH, EDU, SOC and MKT). Cluster analysis is an exploratory tool, which sorts similar units into groups so that the degree of association between the units is maximal if they belong to the same group and minimal otherwise. Various clustering methods are available, but since we did not wish to determine the number of clusters $a^{\prime}$ priori, hierarchical cluster analysis was used.

Figure 2 presents the results of the analysis in the form of a dendogram. From the results it is clear that there is a cluster of European countries to the right on the dendogram that differs from the remaining US states and European countries in important respects. There is also a cluster of US states to the left that appears to be quite different from the rest. What emerges from the analysis is a division into three major clusters: i) A US cluster that we label the "US periphery" (the left branch); ii) a European cluster labeled the "European periphery" (the right branch); and finally iii) a mix of European countries and US regions (in the middle) that combine north-western Europe and the northern US states. We call this cluster the US and European core. 
Figure 2: European countries and US states: A Cluster analysis

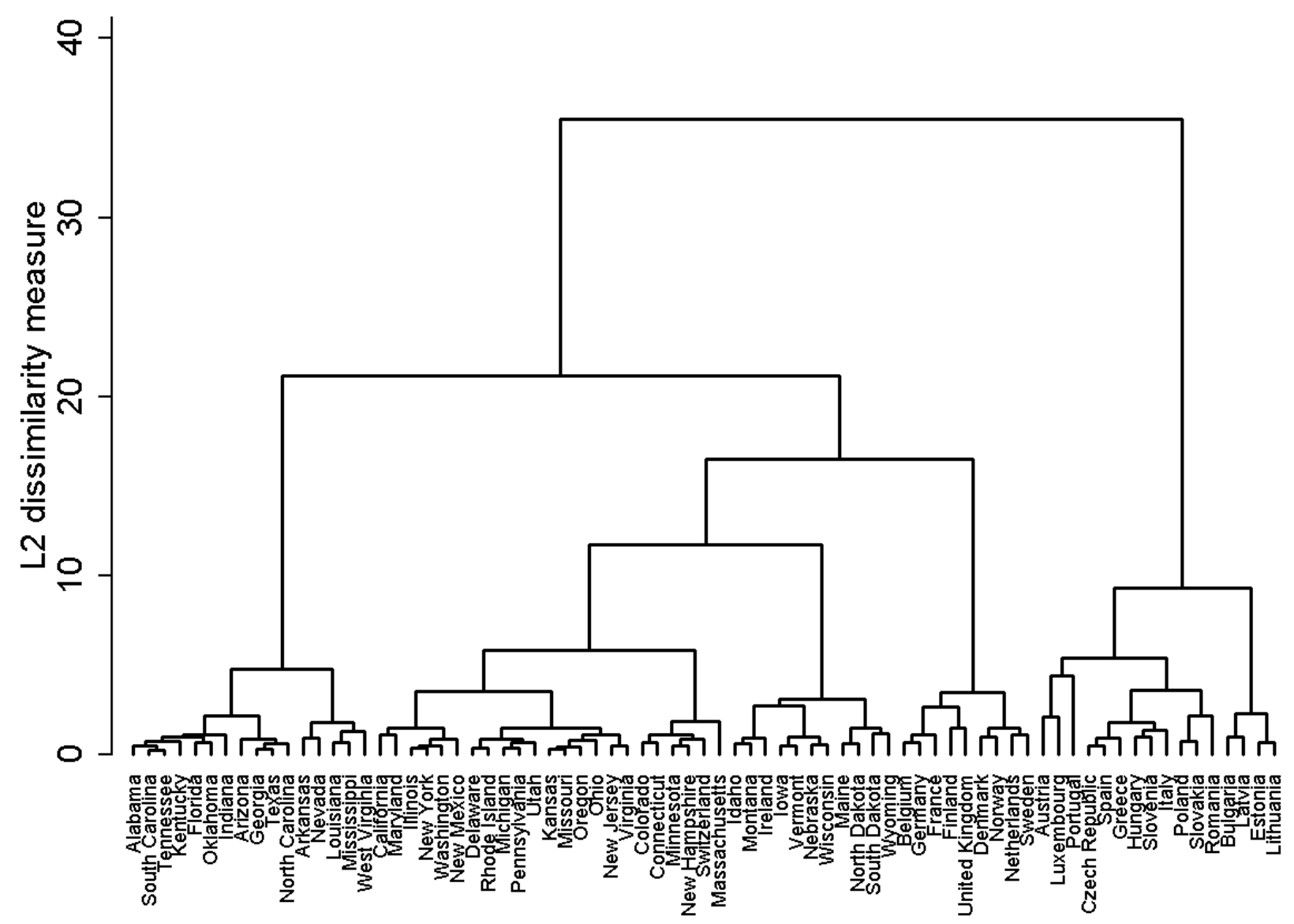

Note. Dendrogram: Ward's linkage and Euclidean (dis)similarity measure. Based on initial levels of TECH, EDU, SOC and MKT.

The characteristics of these three clusters in terms of the variables taken into account by the analysis are presented in Table 7. The 43 entities included in the core compose a relatively homogenous group of regions characterized by high technological capability, a highly educated labor force, and high labor force participation. Social conditions differ considerably though. The 16 regions included in the US periphery differ from the core in that they have less technological capability and a much smaller qualified labor force. Social conditions are also much worse on average. Finally, the European periphery is a relatively heterogeneous cluster characterized by, on average, very low levels of technological capability and labor force participation rates but relatively good social conditions and-at least compared to the US periphery-levels of 
education. Hence, this group of countries seems - to some extent at least- to fit Abramovitz's description of being "technologically backward but socially advanced."

Table 7: Cluster characteristics

\begin{tabular}{l|ll|ll|ll} 
& \multicolumn{2}{|c|}{ US \& Europe core } & \multicolumn{2}{|c|}{ US periphery } & \multicolumn{2}{|c}{ Europe periphery } \\
& Mean & CoV & Mean & CoV & Mean & CoV \\
\hline TECH & 67 & 0.20 & 51 & 0.21 & 29 & 0.60 \\
EDU & 70 & 0.16 & 48 & 0.18 & 52 & 0.38 \\
SOC & 44 & 0.47 & 17 & 0.46 & 62 & 0.35 \\
MKT & 71 & 0.23 & 63 & 0.14 & 27 & 0.75 \\
\hline Number of observations & 43 & & 16 & & 16 &
\end{tabular}

Note: $\mathrm{Cov}$ is the coefficient of variation.

\section{Exploring technological dynamics}

Having dealt with how US states and European countries perform in terms of technological and social capabilities, this section investigates the factors that shape the evolution of technological capability over time. Hence, the dependent variable in our analysis will be the change in technological capability, which is assumed to depend on the ability for learning from others (given by the existence of more advanced capabilities elsewhere), the social capabilities of the region, and other conditioning factors that have been identified in the literature as being relevant for territorial dynamics. The model may be seen as an application of the standard epidemic model of technology diffusion (Metcalfe 1988, Fagerberg et al. 2007) which has been widely used in econometric studies of economic growth and technological change (see Fagerberg 1994 for an overview of some of this literature) or technological change across countries (Fagerberg and Verspagen 1996, Fagerberg et al. 1997, Sala-i-Martin 1996). This model is sometimes characterized as a conditional convergence model, although, depending on the parameterization, it may be consistent with theories predicting convergence (Solow 1956) as well as divergence across countries or regions (Barro and Sala-i-Martin 1995). 
The basic model that we will use is the following:

$$
\begin{aligned}
& \Delta T E C H=T E C H_{1}-T E C H_{0} \\
& =\beta_{0}+\beta_{1} T E C H_{0}+\beta_{2} E D U_{0}+\beta_{3} S O C_{0}+\beta_{4} M K T_{0}+\beta_{5} X_{0}+e(2)
\end{aligned}
$$

in which TECH is an indicators of technological and EDU, SOC and MKT are indicators of social capabilities; $\mathrm{X}$ is a set of other conditioning factors; and $e$ is the standard i.i.d. residual.

As mentioned earlier, knowledge flows may also be conditioned by distance. However, the available research shows that to the extent that this is the case, the effects tend to be fairly local. Typically, spatially conditioned knowledge or technology spillovers are shown to be limited to a radius of about 200 to $400 \mathrm{~km}$ (Feldman and Kogler 2010), which would generally fall within the borders of our relatively large geographical units. But there could be spatial spillovers along shared borders. The variable TECHspill tests for the possibility of interaction effects between the technological capabilities of regions with common borders. This variable represents the technological capabilities of neighboring regions weighted by, for each neighboring region, the common border as a share of the total border of the receiving region: ${ }^{7}$

$$
\text { TECHspill }_{i}=\sum_{\mathrm{j}}\left(\mathrm{TECH}_{\mathrm{j}}-\mathrm{TECH}_{\mathrm{i}}\right) \times \frac{\mathrm{b}_{\mathrm{ij}}}{\sum \mathrm{b}_{\mathrm{i}}}(3)
$$

where $i$ is the receiving region, $j$ is the neighboring region, TECH is as before technological capability, $b_{i j}$ is the length of the common border, and $\sum b_{i}$ denotes the total length of the border. Since, by definition, there is little to learn from those who are less knowledgeable than yourself, we impose the restriction that $\left(\mathrm{TECH}_{\mathrm{j}}-\mathrm{TECH}_{\mathrm{i}}\right)=0$, if $\left(\mathrm{TECH}_{\mathrm{j}}-\mathrm{TECH}_{\mathrm{i}}\right)<0$.

Knowledge or technology spillovers may also depend on movements of people-i.e., the migration of skilled personnel across country or state borders. However, for the present sample,

\footnotetext{
7 The total border of a region includes in addition to borders to neighboring regions in the sample also coastline, shoreline, and borders with countries or regions not included in the present sample. Data on the length of the land borders between the US states was obtained from The State Border Data Set (http://www.econ.umn.edu/ holmes/data/BorderData.html). There are 109 borders between contiguous states. Data on the US-Canada or US-Mexico border length, the length of the coastline and the length of the shoreline of the Great Lakes was obtained from the US statistical Abstract 2010. Data on the length of the land borders between the European countries and their total border length, including coastline, was derived from the on-line edition of the CIA World Factbook.
} 
information on the skill level of migrants was not available. Therefore, following Crescenzi et al. (2007), we used net migration as a share of the total population of the region. ${ }^{8}$

As noted earlier, the analysis also includes variables reflecting relevant territorial characteristics, such as population density (PODEN), SIZE of the region (as indicated by population), both in logs and its degree of specialization (K-index). The latter was, following the method of Midelfart-Knarvik et al. (2002) and Crescenzi et al. (2007), measured as the deviation from an average pattern of specialization of the geographical entities included in the sample. ${ }^{9}$

Table 8 presents the results. Regressions results robust to outliers, based on the procedure suggested by Li (1985), are reported. The first column presents results of the basic model in which change in technological capability is regressed against initial values of the technological and social capabilities. The initial level of technological capability TECH displays a large and significantly negative coefficient, indicating a strong tendency for conditional technological catching up. EDU and SOC are also positive and significant; hence, a well-educated labor force and favorable social conditions are clearly important for the development of technological capability. However, the estimated coefficient for the Labor Market factor score MKT, tough positive as expected, fails to be significant at a $10 \%$ level. Columns 2-6 then one-by-one include the other possible conditioning factors discussed above, but in no case are the estimated impacts significantly different from zero. Since the scope for spatially conditioned spillovers may be different for the individual elements in TECH, we repeated the test for different definitions of TECHspill, but the results hold (results available on request from the authors). Column 7 provides the full model, which includes all variables considered so far. The main results do not change. Finally, a backward search regression was conducted, eliminating the insignificant variables one by one, the results of which lead to the "best model" reported in Column 8 (a 10\% level of statistical significance level was adopted for inclusion in the final reporting).

\footnotetext{
${ }^{8}$ The MIGRATE variable was calculated as the net (im)migration rate in the initial year given by $\left(\mathrm{POP}_{1}-\mathrm{POP}_{0^{-}}\right.$ births+deaths) $/ \mathrm{POP}_{0}$, in which $\mathrm{POP}$ is population and the 0,1 subscripts indicate the beginning and the end of the year, respectively.

${ }^{9}$ The K- index is based on GDP data by 25 sectors according to NACE, rev. 1.1 in Europe and the 2002 NAICS classification in the US. It is computed on the base of the overall sample, i.e. not for Europe and the US separately, because after some adjustments the industry definition at the chosen level of aggregation was very similar. More details on the computation are available from the authors upon request.
} 
Table 8: Exploring technological dynamics

\begin{tabular}{|c|c|c|c|c|c|c|c|c|}
\hline & $(1)$ & (2) & (3) & (4) & $(5)$ & (6) & (7) & (8) \\
\hline \multirow[t]{2}{*}{ Constant } & 0.75 & 0.52 & 0.98 & 1.52 & 0.11 & -1.52 & -11.49 & 1.54 \\
\hline & $(0.33)$ & $(0.20)$ & $(0.42)$ & $(0.54)$ & $(0.01)$ & $(-0.51)$ & (1.04) & $(0.75)$ \\
\hline \multirow[t]{2}{*}{ TECH } & -0.19 & -0.19 & -0.19 & -0.19 & -0.19 & -0.16 & -0.15 & -0.18 \\
\hline & $(5.72) * * *$ & $(4.94) * * *$ & $(5.67)^{* * *}$ & $(4.97) * * *$ & $(4.91)^{* * *}$ & $(4.08) * * *$ & $(3.31)^{* * *}$ & $(6.59) * * *$ \\
\hline \multirow{2}{*}{ EDU } & 0.11 & 0.11 & 0.11 & 0.11 & 0.11 & 0.09 & 0.09 & 0.10 \\
\hline & $(2.84) * * *$ & $(2.80) * * *$ & $(2.80)^{* * *}$ & $(2.82) * * *$ & $(2.76) * * *$ & $(2.39)^{* *}$ & $(2.34) * *$ & $(2.74) * * *$ \\
\hline \multirow[t]{2}{*}{ SOC } & 0.07 & 0.07 & 0.07 & 0.07 & 0.07 & 0.07 & 0.07 & 0.07 \\
\hline & $(3.41)^{* * *}$ & $(3.26) * * *$ & $(3.22)^{* * * *}$ & $(3.41)^{* * *}$ & $(3.39) * * *$ & $(3.48) * * *$ & $(3.28) * * *$ & $(3.37) * * *$ \\
\hline \multirow[t]{2}{*}{ MKT } & 0.02 & 0.02 & 0.02 & 0.01 & 0.02 & 0.01 & 0.03 &.. \\
\hline & $(0.77)$ & $(0.61)$ & $(0.76)$ & $(0.45)$ & $(0.65)$ & $(0.59)$ & $(0.76)$ & \\
\hline TECHspill &.. & $\begin{array}{c}0.01 \\
(0.21)\end{array}$ &.. &.. &.. &.. & $\begin{array}{c}0.02 \\
(0.48)\end{array}$ & .. \\
\hline MIGRATE & .. &.. & $\begin{array}{l}-0.33 \\
(0.57)\end{array}$ & .. & .. &.. & $\begin{array}{l}-0.51 \\
(0.78)\end{array}$ &.. \\
\hline POPDEN &.. & .. & .. & $\begin{array}{l}-0.20 \\
(0.46)\end{array}$ &.. & .. & $\begin{array}{l}-0.24 \\
(0.48)\end{array}$ &.. \\
\hline SIZE & .. &.. &.. &.. & $\begin{array}{c}0.04 \\
(0.08)\end{array}$ &.. & $\begin{array}{c}0.61 \\
(1.00)\end{array}$ &.. \\
\hline K-INDEX & .. & .. &.. &.. &.. & $\begin{array}{c}0.06 \\
(1.16)\end{array}$ & $\begin{array}{c}0.07 \\
(1.22)\end{array}$ &.. \\
\hline $\mathrm{R}^{2}$ & 0.46 & 0.46 & 0.47 & 0.46 & 0.46 & 0.47 & 0.44 & 0.46 \\
\hline AICR & 69.04 & 68.81 & 63.21 & 69.01 & 71.09 & 69.67 & 88.85 & 65.42 \\
\hline BICR & 82.96 & 85.71 & 80.81 & 85.93 & 87.71 & 86.68 & 116.09 & 76.67 \\
\hline Deviance & 828.16 & 830.57 & 835.65 & 827.71 & 827.20 & 813.84 & 874.24 & 838.34 \\
\hline $\mathrm{F}$ & $19.01 * * *$ & $14.90 * * *$ & $15.28 * * *$ & $15.20 * * *$ & $14.83 * * *$ & $15.30 * * *$ & $7.56^{* * *}$ & $25.46 * * *$ \\
\hline $\mathrm{N}$ & 75 & 75 & 75 & 75 & 75 & 75 & 75 & 75 \\
\hline
\end{tabular}

Note: Robust regressions (OLS),rreg command in Stata 11.Absolute value of t-statistics in brackets; *, **, *** denote significance at the 10,5 and 1 percent levels. 
Hence, while there is strong support for the hypothesis that the scope for technology diffusion and well-developed social capabilities matter, there is little support for the other variables included in the model. This result may be influenced by heterogeneity in technological and territorial dynamics across the two continents, as suggested by Crescenzi et al. (2007). To allow for this possibility, the two last models of Table 8 were tested with Europe-specific and Cluster-specific slope dummies for all variables included. An F-test was conducted on the hypothesis that these interaction terms were jointly equal to zero. In the case of the "best model" (column 8, Table 8), the results from this test indicate that there are no significant differences either across the two continents or across the three clusters identified above in terms of the impact of initial technological capability, the educational standard of the labor force, or the degree of social cohesion. However, for the "full model" (column 7, Table 8), the hypothesis that the interaction terms were all equal to zero is rejected at the $10 \%$ and $1 \%$ levels of significance for the two continents and the three clusters, respectively. Hence, in order to explore in more depth the possible sources of heterogeneity in technological and territorial dynamics across the US and Europe, we repeated the tests of columns 2 to 6 in Table 8, but this time allowing for possible differences across the US and Europe in the impact of the additional variable in question. The results of these tests are reported in Table 9. 
Table 9a: Technological dynamics: Testing for differences across the US and Europe

\begin{tabular}{|c|c|c|c|c|c|c|}
\hline & (1) & (2) & (3) & (4) & (5) & (6) \\
\hline Constant & $\begin{array}{c}2.46 \\
(1.04)\end{array}$ & $\begin{array}{c}1.47 \\
(0.58)\end{array}$ & $\begin{array}{c}2.68 \\
(1.26)\end{array}$ & $\begin{array}{c}3.64 \\
(1.47)\end{array}$ & $\begin{array}{l}15.41 \\
(1.67)\end{array}$ & $\begin{array}{l}-0.12 \\
(0.04)\end{array}$ \\
\hline TECH & $\begin{array}{l}-0.20 \\
(6.19)^{* * *}\end{array}$ & $\begin{array}{l}-0.16 \\
(5.32)^{* * *}\end{array}$ & $\begin{array}{l}-0.19 \\
(6.82)^{* * *}\end{array}$ & $\begin{array}{l}-0.15 \\
(4.39)^{* * *}\end{array}$ & $\begin{array}{l}-0.13 \\
(3.54) * * *\end{array}$ & $\begin{array}{l}-0.11 \\
(2.81)^{* * *}\end{array}$ \\
\hline EDU & $\begin{array}{l}0.09 \\
(2.33)^{* *}\end{array}$ & $\begin{array}{l}0.09 \\
(2.20)^{* *}\end{array}$ & $\begin{array}{l}0.11 \\
(2.98)^{* * *}\end{array}$ & $\begin{array}{l}0.09 \\
(2.16)^{* *}\end{array}$ & $\begin{array}{c}0.07 \\
(1.50)\end{array}$ & $\begin{array}{c}0.05 \\
(1.12)\end{array}$ \\
\hline SOC & $\begin{array}{c}0.03 \\
(0.98)\end{array}$ & $\begin{array}{l}0.06 \\
(2.63)^{* *}\end{array}$ & $\begin{array}{c}0.04 \\
(1.47)\end{array}$ & $\begin{array}{c}0.04 \\
(1.50)\end{array}$ & $\begin{array}{c}0.02 \\
(0.74)\end{array}$ & $\begin{array}{l}0.05 \\
(2.15)^{* *}\end{array}$ \\
\hline MKT & $\begin{array}{c}0.03 \\
(1.39)\end{array}$ & .. &.. &.. &.. & .. \\
\hline EUROPE*MKT & $\begin{array}{l}0.07 \\
(2.45)^{* * *}\end{array}$ & .. & .. & .. & .. & .. \\
\hline TECHspill & .. & $\begin{array}{l}-0.01 \\
(0.20)\end{array}$ & .. & .. & .. & .. \\
\hline EUROPE*TECHspill & .. & $\begin{array}{c}0.05 \\
(1.18)\end{array}$ & .. & .. & .. & .. \\
\hline MIGRATE & .. &.. & $\begin{array}{l}-0.61 \\
(1.03)\end{array}$ & .. & .. & .. \\
\hline EUROPE*MIGRATE & .. & .. & $\begin{array}{c}5.02 \\
(1.71)^{*}\end{array}$ & .. & .. & .. \\
\hline POPDEN & .. & .. &. & $\begin{array}{l}-0.66 \\
(1.37)\end{array}$ & .. & .. \\
\hline EUROPE*POPDEN & .. & .. & .. & $\begin{array}{c}0.58 \\
(1.45)\end{array}$ & .. & .. \\
\hline SIZE & .. & .. & .. &.. & $\begin{array}{l}-0.88 \\
(1.53)\end{array}$ & .. \\
\hline EUROPE*SIZE & .. & .. & .. & .. & $\begin{array}{c}0.24 \\
(1.73)^{*}\end{array}$ & .. \\
\hline K-INDEX & .. & .. & .. & .. &.. & $\begin{array}{c}0.04 \\
(0.67)\end{array}$ \\
\hline EUROPE*K-INDEX & .. & .. & .. & .. & .. & $\begin{array}{c}0.07 \\
(1.63)\end{array}$ \\
\hline
\end{tabular}




\begin{tabular}{lcccccc}
\hline $\mathrm{R}^{2}$ & 0.49 & 0.46 & 0.49 & 0.49 & 0.48 & 0.47 \\
$\mathrm{AICR}$ & 75.16 & 73.51 & 60.79 & 57.41 & 67.69 & 77.68 \\
$\mathrm{BICR}$ & 91.29 & 90.01 & 78.68 & 75.56 & 84.58 & 93.84 \\
Deviance & 751.23 & 809.36 & 808.62 & 823.18 & 805.08 & 778.32 \\
$\mathrm{~F}$ & $16.77 * * *$ & $14.75 * * *$ & $16.33 * * *$ & $15.92 * * *$ & $15.32 * * *$ & $15.43 * * *$ \\
$\mathrm{~N}$ & 75 & 75 & 75 & 75 & 75 & 75 \\
\hline
\end{tabular}

Note: Robust regressions (OLS),rreg command in Stata 11.Absolute value of t-statistics in brackets; *,**,*** denote significance at the 10,5 and 1 percent levels. 
Table 9b: Technological dynamics: Testing for differences across the clusters

\begin{tabular}{|c|c|c|c|c|c|c|}
\hline & (1) & (2) & (3) & (4) & (5) & (6) \\
\hline \multirow[t]{2}{*}{ Constant } & -2.55 & 1.87 & 1.17 & -1.69 & 4.16 & -1.86 \\
\hline & $(0.82)$ & $(0.73)$ & $(0.55)$ & $(0.55)$ & $(0.64)$ & $(0.48)$ \\
\hline \multirow[t]{2}{*}{ TECH } & -0.20 & -0.16 & -0.18 & -0.12 & -0.13 & -0.13 \\
\hline & $(5.91) * * *$ & $(5.44) * * *$ & $(6.41)^{* * *}$ & $(3.33) * * *$ & $(3.51)^{* * *}$ & $(2.83) * * *$ \\
\hline \multirow[t]{2}{*}{ EDU } & 0.16 & 0.08 & 0.12 & 0.14 & 0.12 & 0.08 \\
\hline & $(3.61) * * *$ & $(2.08)^{* *}$ & $(3.33)^{* * *}$ & $(3.25)^{* * *}$ & $(2.81)^{* * *}$ & $(1.74)^{*}$ \\
\hline \multirow[t]{2}{*}{ SOC } & 0.04 & 0.05 & 0.05 & 0.06 & 0.06 & 0.07 \\
\hline & $(1.58)$ & $(2.46)^{* *}$ & $(2.22)^{* *}$ & $(2.40)^{* *}$ & $(2.28)^{* *}$ & $(2.91)^{* * *}$ \\
\hline MKT & $\begin{array}{c}0.03 \\
(1.34)\end{array}$ & .. & .. & .. & .. & .. \\
\hline Cluster1*MKT & $\begin{array}{c}0.01 \\
(0.53)\end{array}$ & .. & .. & .. & .. & .. \\
\hline Cluster $3 *$ MKT & $\begin{array}{l}0.11 \\
(2.18) * *\end{array}$ & & & & & \\
\hline TECHspill &.. & $\begin{array}{c}0.04 \\
(1.20)\end{array}$ & .. & .. & .. & .. \\
\hline Cluster1*TECHspill & .. & $\begin{array}{l}-0.06 \\
(1.40)\end{array}$ & .. & .. & .. & .. \\
\hline Cluster3*TECHspill & & $\begin{array}{c}0.00 \\
(0.04)\end{array}$ & & & & \\
\hline MIGRATE & .. &.. & $\begin{array}{l}-1.22 \\
(1.16)\end{array}$ & .. & .. & .. \\
\hline Cluster1*MIGRATE & .. & .. & $\begin{array}{c}1.06 \\
(0.84)\end{array}$ & .. & .. & .. \\
\hline Cluster $3 *$ MIGRATE & & & $\begin{array}{c}3.66 \\
(1.08)\end{array}$ & & & \\
\hline POPDEN & .. & .. &.. & $\begin{array}{l}-0.74 \\
(1.66)\end{array}$ & .. & .. \\
\hline Cluster1*POPDEN & .. & .. & .. & $\begin{array}{c}0.49 \\
(1.17)\end{array}$ & .. & .. \\
\hline Cluster3*POPDEN & & & & $\begin{array}{l}1.02 \\
(2.25)^{* *}\end{array}$ & & \\
\hline
\end{tabular}




\begin{tabular}{|c|c|c|c|c|c|c|}
\hline SIZE & .. & .. & .. & .. & $\begin{array}{l}-0.44 \\
(1.00)\end{array}$ & .. \\
\hline Cluster1*SIZE & .. & .. & .. & .. & $\begin{array}{c}0.08 \\
(0.75)\end{array}$ & .. \\
\hline Cluster3*SIZE & & & & & $\begin{array}{c}0.23 \\
(1.81)^{*}\end{array}$ & \\
\hline K-INDEX & .. & .. & .. & .. & .. & $\begin{array}{c}0.07 \\
(1.30)\end{array}$ \\
\hline Cluster1*K-INDEX & .. & .. & .. & .. & .. & $\begin{array}{c}0.00 \\
(0.01)\end{array}$ \\
\hline Cluster3*K-INDEX & & & & & & $\begin{array}{c}0.03 \\
(0.52)\end{array}$ \\
\hline $\mathrm{R}^{2}$ & 0.47 & 0.48 & 0.44 & 0.48 & 0.45 & 0.46 \\
\hline AICR & 84.54 & 70.77 & 79.08 & 79.39 & 86.84 & 81.13 \\
\hline BICR & 102.31 & 90.76 & 98.67 & 98.01 & 104.43 & 99.68 \\
\hline Deviance & 748.47 & 800.77 & 907.39 & 754.89 & 774.59 & 795.46 \\
\hline $\mathrm{F}$ & $13.21 * * *$ & $12.95 * * *$ & $12.52 * * *$ & $14.05 * * *$ & $12.54 * * *$ & $12.06 * * *$ \\
\hline $\mathrm{N}$ & 75 & 75 & 75 & 75 & 75 & 75 \\
\hline
\end{tabular}

Note: Robust regressions (OLS), rreg command in Stata 11. Absolute value of t-statistics in brackets; *,***** denote significance at the 10, 5 and 1 percent levels. 
In general, the results do not provide strong support for the hypothesis of significant differences within the sample in terms of what shapes technological dynamics. The only notable exception is for the Labor Market factor, which is found to matter more in Europe, and particularly in the European periphery, than in the US. This result, which is significant at the 5\% level, indicates that failing to keep unemployment low (and participation in the labor force high), has a cost beyond immediate economic effects, by hampering long term growth of technological capability and, hence, the future development of the country. Interestingly, the introduction of continent and cluster specific terms for the impact of the Labor Market renders the effect of Social Cohesion insignificant, indicating perhaps that in Europe high labor market participation and well developed Social Cohesion may go hand in hand and are thus difficult to distinguish in terms of their effects.

There is more diversity if the weaker $10 \%$ significance criterion for acceptance of continent or cluster specific effects on variables impact is adopted. For example, in this case there is some evidence suggesting - in contrast to earlier research (Crescenzi et al. 2007) - that the effects of migration on growth of technological capability are more positive in Europe than in the US. The same holds for regional size and, in the case of the European periphery, also population density. However, and again in contrast to previous research (Crescenzi et al. 2007), there are no significant differences across continents or clusters with respect to the effects of spatially conditioned knowledge, technology spillovers, or specialization.

As pointed out above, some of these results run counter to those reported by Crescenzi et al. (2007) for their earlier time period. They found that spatially conditioned technology spillovers mattered in Europe but not in the US, while this relationship was vice-versa for migration; however, these findings are not supported here. It should be noted, though, that there are a number of differences between the present study and that of Crescenzi et al. First, as pointed out in the introduction, their dependent variable is patent growth, not the broader technological capability measure preferred here. However, replacing our technological capability variable with a patent-based measure turned out to have no effect on the results (available from the authors on request). Second, Crescenzi et al. compare US cities to European regions (at the NUTS 1-2 level, i.e., countries or parts thereof), and although it cannot be excluded a priori that this leads a different result, it is difficult to see why that would be the case. Third, the present study considers a more recent time period and includes the countries in Eastern Europe (which 
were excluded by Crescenzi et al.). This may well explain some of the differences, particularly with respect to migration. During the 1990s the EU started on a reform path (the internal market), with the explicit goal of making cross-border economic activities, including migration, easier; at the same time, the new democracies in Eastern Europe gradually became more integrated into the European economy. Increased migration of relatively skilled personnel, particularly from the East to the West, followed in the wake of these changes. This increased mobility of personnel, which while perhaps a mixed blessing for Eastern Europe, was most likely beneficial for a number of European countries, which improved their technological capabilities rapidly during this period, such as Spain, Luxemburg and Ireland, which all had net inward migration rates far above the European average.

Figure 2: Estimated contributions to change in technological capability 2000-2007, relative to sample average

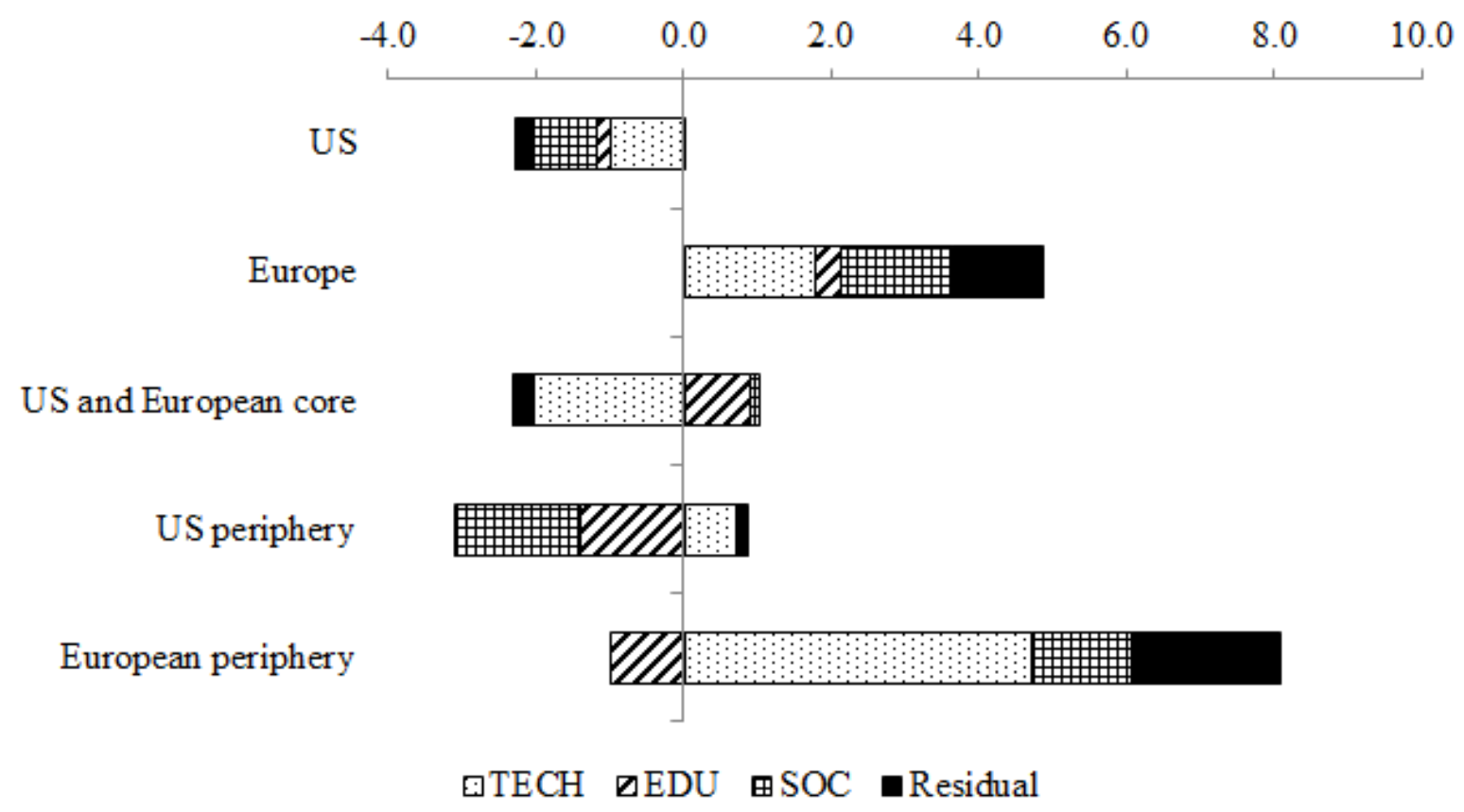

Note: Based on column 8 in Table 8.

Figure 2 illustrates how the variables taken into account here explain the changes in technological capability relative to the sample average in the two continents (three clusters). The figure is based on the best model in Table 8 (column 8). The US states were, on average, more advanced technologically to begin with than their European counterparts, indicating a smaller 
potential for learning from others. This contributed to somewhat slower growth in the US. This outcome is, however, accentuated by lack of social cohesion, which drags down growth in the US while boosting it in Europe. The negative effect of lacking social cohesion in the US is particularly evident for the US periphery, which is falling behind technologically. The periphery's slow growth relative to the average also reflects a failure to invest sufficiently in education. In contrast, the European periphery is catching up at rapid rate due to a much larger potential for learning supported by favorable social conditions. There is some indication, however, that lack of investments in education is hampering the growth in these countries too, though less so than for the US periphery. Some of the success of the countries in the European periphery, and hence for Europe as a whole, remains unaccounted for by the model, which can be attributed perhaps to the fact that the majority of the countries in this cluster consists are socalled "transition countries" (former socialist economies).

\section{Conclusions}

Around the turn of the millennium, policy makers, particularly in Europe but also elsewhere, began explaining the inability to realize economic objectives on the lack of $R \& D$ investments. Hence, increasing $R \& D$ investments was seen as an appropriate strategy for

addressing the lack of economic growth. While R\&D are certainly important, both theory and the empirical evidence suggest that $R \& D$ investments need to be accompanied by a number of complementary technological, social and institutional factors, to deliver desired results. However, the real challenge is to exploit this insight in research. Moreover, most previous work on this issue compares the US as whole to individual European countries, which given the difference in size and the heterogeneous character of U.S. states is not the most appropriate comparison. This paper therefore changes the unit of observation from the entire U.S. economy to individual states, which arguably are more comparable to European countries than the US as whole.

The theoretical perspective that has guided our research suggests that it is necessary to take into account both technological and social capabilities. As for technological capability, which includes not only R\&D but also a number of other aspects related to exploration and 
exploitation of knowledge, the results suggest that most European countries are just as capable as US states. Hence, the worry expressed by many European policy makers over Europe lagging behind the US along this dimension appears misguided. In fact, the major difference between the two continents is not so much related to their top performers as to the fact that Europe includes a number of formerly Socialist countries in Eastern Europe, which understandably have not yet managed to generate technological capabilities comparable to those of Western Europe. As for social capabilities, the analysis suggests that while education is a strong point for Europe, the ability to engage the population in productive activities is not, at least when compared to the US. On the latter dimension there is a marked difference across the two continents. However, the biggest difference is to be found in what has been termed "social cohesion," which reflects norms, values, and institutions that facilitate economic activities, and for which US states tend to lag considerably behind Europe.

The results reached in this paper give strong support for the theoretical perspective outlined in section 2. The development of technological capability is not a zero-sum game. Learning from the efforts of others is an important factor contributing to technological capability, particularly in technologically less advanced regions. However, as pointed out by Abramovitz, "The potential for rapid growth is strong not when it is backward without clarification, but rather when it is technologically backward but socially advanced" (Abramovitz 1986: p. 388). The results reported here are consistent with this perspective: Well developed social capabilities impact the degree to which countries and regions succeed in tapping into the global knowledge pool and exploiting it to their own advantage. Policy makers who do not take these lessons into account may fail to reach the desired results of the policies they pursue.

It has been common among policy makers, media and also scholars who study the difference in performance across the US and Europe to assume that the two systems work rather differently. The research presented here does not support this perspective but rather, suggests — at least as far as technological dynamics is concerned - that the underlying factors that influence dynamics among European countries as well as US states tend to be the same in most cases. However, since both Europe and the US are quite heterogeneous entities, the observed dynamics may well differ, as may the future growth challenges ahead. Due to its recent history, Europe has much larger internal differences in technological capability, and this has contributed to more vibrant internal dynamics, with several previously Socialist countries in the East catching up 
technologically at rapid speed. The challenge for European policy makers, in a time of crisis, will be to sustain this fortuitous trend by continuing to invest in education and preventing social conditions, for example unemployment, from deteriorating. In contrast to the European example, technological differences in the US are widening, in large part due to the combination of skill shortages and adverse social conditions, which are especially characteristic for lagging regions. To reverse this trend, policies focusing narrowly on investments in R\&D will not suffice. What is needed are comprehensive policies targeting the skills of the population and the broader social conditions that impact technological and territorial dynamics. 


\section{References}

Abramovitz, M. (1986) Catching Up, Forging Ahead, and Falling Behind. Journal of Economic History, 46, 386406.

Abramovitz, M. (1994a) The Origins of the Post-war Catch-Up and Convergence Boom, in Fagerberg, J., Verspagen, B., von Tunzelman, N. (Eds.), The Dynamics of Technology, Trade and Growth. Edward Elgar, Aldershot, pp. 21-52.

Abramovitz, M. (1994b) Catch-up and Convergence in the Postwar Growth Boom and After, in Baumol, W. J., Nelson, R. R., Wolf, E. N. (Eds.), Convergence of Productivity - Crossnational studies and historical evidence. Oxford, Oxford University Press, pp. 86-125.

Adelman, I. and Morris, C. T. (1965) A Factor Analysis of the Interrelationship Between Social and Political Variables and Per Capita Gross National Product. Quarterly Journal of Economics, 79, 555-578.

Aghion, P. and Howitt, P. (1992) A Model of Growth through Creative Destruction. Econometrica, 60, 323-351.

Audretsch, D., and Feldman, M. (1996).Knowledge spillovers and the geography of innovation and production. American Economic Review, 86: 630-640.

Bairoch, P. (1988) Cities and Economic Development. Chicago: University of Chicago Press.

Barro, E. J. and Sala-i-Martin, X. (1995) Economic Growth. New York: McGraw-Hill

Bottazzi, L. and Peri, G. (2003) Innovation and spillovers in regions: Evidence from European patent data. European Economic Review, 47, 687-710.

Braczyk, H-J., Cooke, P. and Heidenreich, M. (1998) Regional Innovation Systems: The Role of Governances in a Globalized World. Routledge, London.

Cohen, W. M. and Levinthal., D. A. (1990) Absorptive Capacity: A New Perspective on Learning and Innovation. Administrative Science Quarterly, 35, 128-152.

Crescenzi, R., Rodríguez-Pose, A. and Storper, M. (2007) The territorial dynamics of Innovation: A Europe-United States Comparison. Journal of Economic Geography, 7, 673709.

Criscuolo, P. and Verspagen, B. (2008) Does it matter where patent citations come from? Inventor vs. examiner citations in European patents. Research Policy, 37, 1892-1908.

Denison, E. F. (1967) Why growth rates differ. Washington, DC: Brookings Institution. 
Edquist, C. (2004) Systems of Innovation: Perspectives and Challenges, in Fagerberg, J., Mowery, D., Nelson, R. (Eds.), The Oxford Handbook of Innovation. Oxford University Press, Oxford, pp. 181-208.

Fagerberg, J. (1994) Technology and International Differences in Growth Rates. Journal of Economic Literature, 32, 1147-1175.

Fagerberg, J., Mowery, D. and Nelson, R. (2004) The Oxford Handbook of Innovation. Oxford University Press, Oxford.

Fagerberg, J. and Srholec, M. (2005) Catching up: What are the Critical Factors for Success? Vienna, UNIDO, Background paper for the UNIDO Industrial Development Report 2005.

Fagerberg, J., M. Srholec, and Knell, M. (2007) The Competitiveness of Nations: Why Some Countries Prosper While Others Fall Behind. World Development, 35, 1595-1620.

Fagerberg, J. and Srholec, M. (2008) National Innovation Systems, Capabilities and Economic Development. Research Policy, 37, 1417-1435.

Fagerberg, J. and Verspagen, B. (1996) Heading for Divergence? Regional Growth in Europe Reconsidered. Journal of Common Market Studies, 34, 431-448.

Fagerberg, J., Verspagen, B. and Caniëls, M. (1997) Technology, Growth and Unemployment across European Regions. Regional Studies, 31, 457-466.

Feldman, M. P. (1994) The Geography of Innovation. Dordrecht: Kluwer Academic Publishers. Feldman, M. P. and Audretsch, D. B. (1999) Innovation in Cities: Science-based Diversity, Specialization, and Localized Competition. European Economic Review, 43, 409-429.

Feldman, M. P. and Kogler D. F. (2010) Stylized Facts in the Geography of Innovation, in Hall B. and Rosenberg N. (eds) Handbook of Economics of Technical Change. Oxford: Elsevier.

Gerschenkron, A. (1962) Economic Backwardness in Historical Perspective. The Belknap Press, Cambridge (MA).

Gregory, M., Salverda, W. and Schettkat, R. (2007) Services and Employment: Explaining the U.S.-European Gap. Princeton: Princeton University Press.

Grossman, G. M. and Helpman, E. (1991) Innovation and Growth in the Global Economy. The MIT Press, Cambridge (MA).

Hayek, F. A. (1945) The Use of Knowledge in Society. American Economic Review, 35, 519530.

Henderson, J. V. (2010) Cities And Development. Journal of Regional Science, 50, 515-540. 
Iammarino S. and McCain P. (2006) The structure and evolution of industrial clusters: transactions, technology and knowledge spillovers. Research Policy, 35, 1018-1036.

Jacobs, J. (1969) The Economy of Cities. New York: Vintage Books.

Jaffe, A., Trajtenberg, M. and Henderson, R. (1993) Geographic localization of knowledge spillovers as evidenced by patent citations. Quarterly Journal of Economics, 108, 577-598.

Keller, W. (2002) Geographic Localization of International Technology Diffusion. American Economic Review, 92, 120-142.

Kim L. (1980) Stages of development of industrial technology in a developing country: a model. Research Policy, 9, 254-277.

Kim, L. (1997) Imitation to Innovation: The Dynamics of Korea's Technological Learning. Harvard Business School Press, Harvard.

King, D.A. (2004) The scientific impact of nations: What different countries get for their research spending. Nature, 430, 311-316.

Kline, S. J. and Rosenberg, N. (1986) An Overview of Innovation. In R. Landau and N. Rosenberg (eds) The Positive Sum Strategy: Harnessing Technology for Economic Growth, Washington D.C.: National Academy Press, pp. 275-304.

Lall, S. (1992) Technological Capabilities and Industrialization. World Development, 20, 165186.

Landes, D. (1998) The wealth and poverty of nations. London: Abacus.

Lundvall, B. A. (1992) National Systems of Innovation: Towards a Theory of Innovation and Interactive Learning. Pinter Publishers, London.

Li, G. (1985) Robust regression. In Exploring Data Tables, Trends, and Shapes, ed. D. C. Hoaglin, F. Mosteller, and J. W. Tukey, New York: Wiley, pp. 281-340.

Maurseth, P. B. and Verspagen, B. (2002) Knowledge Spillovers in Europe: A Patent Citations Analysis. Scandinavian Journal of Economics, 104, 531-545.

Metcalfe, J.S. (1988) The Diffusion of Innovation: An Interpretive Survey, in (eds.) G. Dosi et al, Technological Change and Economic Theory, Francis Pinter, London.

Midelfart-Knarvik, K. H., Overman, H.G., Redding, S. and Venables, A. J. (2002) The location of European industry. European Economy, 2, 216-273.

Moreno, R., Paci, R. and Usai, S. (2005) Spatial spillovers and innovation activity in European regions. Environment and Planning A, 37, 1793-1812. 
Nelson, R. (1993) National Innovation Systems: A Comparative Analysis. Oxford University Press, New York.

OECD (2002) Frascati Manual: Proposed Standard Practices for Surveys on Research and Experimental Development. $6^{\text {th }}$ edition. Paris: OECD.

Polanyi, M. (1958) Personal Knowledge: Towards a Post-Critical Philosophy. London: Routledge.

Polanyi, M. (1966) The Tacit Dimension. Peter Smith, Gloucester. Mass.

Portes, A. (1998) Social Capital: Its Origins and Applications in Modern Sociology. Annual Review of Sociology, 24, 1-24.

Putnam, R. (1993) Making Democracy Work. Princeton: Princeton University Press.

Romer, P. M. (1990) Endogenous Technological Change. Journal of Political Economy, 98, 71102.

Sala-i-Martin, X. (1996) Regional Cohesion: Evidence and Theories of Regional Growth and Convergence. European Economic Review, 40, 325-52.

Salter, A., D’Este, P1, Pavitt, K., Scott, A., Martin, B., Geuna, A., Nightingale, P., Patel, P. (2000) Talent, Not Technology: The Impact of Publicly Funded Research on Innovation in the UK. Sussex, SPRU.

Smith, K. (2004) Measuring Innovation. In Fagerberg, J., Mowery. D. and R.R. Nelson (eds), The Oxford Handbook of Innovation, Oxford: Oxford University Press.

Solow, R. M. (1956) A Contribution to the Theory of Economic Growth. Quarterly Journal of Economics, 70, 65-94.

Veblen, T. (1915) Imperial Germany and the Industrial Revolution. New York: Macmillan.

Woolcock, M., Narayan, D. (2000) Social Capital: Implications for Development Theory, Research, and Policy. World Bank Research Observer, 15, 225-250. 


\begin{tabular}{|c|c|c|c|c|c|}
\hline \multirow[t]{2}{*}{ Indicator } & \multirow[t]{2}{*}{ Unit } & \multicolumn{2}{|c|}{ Source of data } & \multirow{2}{*}{\multicolumn{2}{|c|}{ Period }} \\
\hline & & US states & EU countries & & \\
\hline $\begin{array}{l}\text { Scientific articles: The number of articles } \\
\text { published in journals classified and covered by } \\
\text { Science Citation Index (SCI) and Social } \\
\text { Sciences Citation Index (SSCI); fractional } \\
\text { assignments. }\end{array}$ & $\begin{array}{l}\text { Per million } \\
\text { working-age } \\
\text { population }\end{array}$ & The Patent Board & $\begin{array}{l}\text { NSF, Science } \\
\text { Engineering } \\
\text { Indicators } 2010\end{array}$ & 2000 & 2007 \\
\hline $\begin{array}{l}\text { International patents: The number of PCT } \\
\text { patent applications; fractional counts; by } \\
\text { inventor(s)'s country(ies) of residence and by } \\
\text { the priority date }\end{array}$ & $\begin{array}{l}\text { Per million } \\
\text { working-age } \\
\text { population }\end{array}$ & $\begin{array}{ll}\text { OECD } & \text { REGPAT } \\
\text { Database } & \end{array}$ & $\begin{array}{l}\text { OECD } \\
\text { Database }\end{array}$ & 2000 & 2007 \\
\hline $\begin{array}{l}\text { Doctorate: The number of science and } \\
\text { engineering doctorate graduates (level } 6 \text { of } \\
\text { ISCED 1997) }\end{array}$ & $\begin{array}{l}\text { Per million } \\
\text { working-age } \\
\text { population }\end{array}$ & $\begin{array}{l}\text { NSF, S\&E State } \\
\text { Profiles }\end{array}$ & Eurostat on-line & 2000 & 2007 \\
\hline $\begin{array}{l}\text { Business R\&D : Expenditures on R\&D } \\
\text { performed by the business sector }\end{array}$ & $\%$ of GDP & $\begin{array}{l}\text { OECD.Stat Regional } \\
\text { Statistics }\end{array}$ & Eurostat on-line & 2000 & 2007 \\
\hline $\begin{array}{l}\text { University R\&D : Expenditures on R\&D } \\
\text { performed by the higher education and private } \\
\text { and non-profit sectors }\end{array}$ & $\%$ of GDP & $\begin{array}{l}\text { OECD.Stat Regional } \\
\text { Statistics }\end{array}$ & Eurostat on-line & 2002 & 2007 \\
\hline $\begin{array}{l}\text { Government R\&D: Expenditures on R\&D } \\
\text { performed by the government sector }\end{array}$ & $\%$ of GDP & $\begin{array}{l}\text { OECD.Stat Regional } \\
\text { Statistics }\end{array}$ & Eurostat on-line & 2002 & 2007 \\
\hline $\begin{array}{l}\text { Venture capital: Early stage, expansion and } \\
\text { replacement venture capital investments }\end{array}$ & $\%$ of GDP & $\begin{array}{l}\text { SSTI and the PWC } \\
\text { Moneytree Report }\end{array}$ & Eurostat on-line & 2000 & 2007 \\
\hline $\begin{array}{l}\text { Tertiary education: Attainment of tertiary } \\
\text { education (levels 5-6 of ISCED 1997) }\end{array}$ & $\%$ of labor force & $\begin{array}{l}\text { OECD.Stat Regional } \\
\text { Statistics }\end{array}$ & Eurostat on-line & 2000 & \\
\hline $\begin{array}{l}\text { Professionals: Senior officials, professionals, } \\
\text { technicians and associate professionals; } 11-31 \\
\text { codes of SOC in the US and 1-3 codes of } \\
\text { ISCO } 88 \text { in Europe. }\end{array}$ & 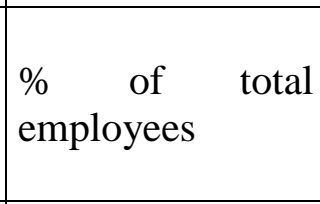 & $\begin{array}{l}\text { BLS, Occupational } \\
\text { Employment } \\
\text { Statistics }\end{array}$ & Eurostat on-line & 2000 & \\
\hline $\begin{array}{l}\text { Teacher-pupil ratio: The ratio of teachers to } \\
\text { students in elementary and secondary public } \\
\text { schools (levels 1-3 of ISCED 1997) }\end{array}$ & $\begin{array}{l}\text { Teachers per } \\
\text { student }\end{array}$ & $\begin{array}{l}\text { National Center for } \\
\text { Education Statistics }\end{array}$ & Eurostat on-line & 2000 & \\
\hline
\end{tabular}




\begin{tabular}{|c|c|c|c|}
\hline $\begin{array}{l}\text { Income inequality: The ratio of total income } \\
\text { received by the } 20 \% \text { of the population with } \\
\text { the highest income (top quintile) to that } \\
\text { received by the } 20 \% \text { of the population with } \\
\text { the lowest income (lowest quintile). }\end{array}$ & $\begin{array}{l}\text { Top per lowest } \\
\text { quintile }\end{array}$ & $\begin{array}{l}\text { American Human } \\
\text { Development Project }\end{array}$ Eurostat on-line & $\begin{array}{l}2001-2003 \text { in the } \\
\text { US and } 2001 \text { or the } \\
\text { nearest in Europe }\end{array}$ \\
\hline $\begin{array}{l}\text { Election turnout: Voter turnout in } \\
\text { presidential elections in the US and } \\
\text { parliamentary elections in Europe }\end{array}$ & $\begin{array}{l}\% \text { of voting-age } \\
\text { population }\end{array}$ & $\begin{array}{l}\text { U.S. Census Bureau; } \\
\text { The } \quad \text { Statistical } \\
\text { Abstract: } \\
\text { edition }\end{array}$ & 2000 or the nearest \\
\hline $\begin{array}{l}\text { Homicide: The number of homicides; i.e. } \\
\text { murder and nonnegligent manslaughter }\end{array}$ & \begin{tabular}{ll|}
$\begin{array}{l}\text { Per million } \\
\text { adults }\end{array}$ & \\
\end{tabular} & $\begin{array}{l}\text { Uniform Crime } \\
\text { Reporting Statistics }\end{array}$ & 2000 \\
\hline $\begin{array}{l}\text { Unemployment: Unemployment rate given by } \\
\text { the number of unemployed in the labour force }\end{array}$ & $\%$ of labor force & $\begin{array}{l}\text { BEA, Geographic } \\
\text { Profile of } \\
\text { Employment and Eurostat on-line } \\
\text { Unemployment }\end{array}$ & 2000 \\
\hline $\begin{array}{l}\text { Labour force participation: The ratio of the } \\
\text { labour force to the working age population, } \\
\text { where the labour force is the sum of the } \\
\text { numbers of persons employed and } \\
\text { unemployed. }\end{array}$ & $\begin{array}{l}\% \text { of labor force } \\
\text { in working-age } \\
\text { population }\end{array}$ & $\begin{array}{l}\text { BEA, Geographic } \\
\text { Profile of } \\
\text { Employment and Eurostat on-line } \\
\text { Unemployment }\end{array}$ & 2000 \\
\hline $\begin{array}{l}\text { Migration: The net migration rate given by } \\
\text { the change of population plus deaths minus } \\
\text { births as the proportion of the initial } \\
\text { population. }\end{array}$ & $\%$ of population & $\begin{array}{l}\text { U.S. Census Bureau, Eurostat on-line } \\
\text { Population Estimates }\end{array}$ & 2000 \\
\hline $\begin{array}{l}\text { Population density: The number of people } \\
\text { per surface area }\end{array}$ & People per $\mathrm{km}^{2}$ & $\begin{array}{l}\text { OECD.Stat Regional Eurostat on-line } \\
\text { Statistics }\end{array}$ & 2000 \\
\hline Population: The number of inhabitants & People & $\begin{array}{l}\text { OECD.Stat Regional Eurostat on-line } \\
\text { Statistics }\end{array}$ & 2000 \\
\hline $\begin{array}{l}\text { K-index: The deviation from an average } \\
\text { pattern of specialization of the geographical } \\
\text { entities included in the sample based on GDP } \\
\text { data in } 25 \text { sectors. }\end{array}$ & Index & $\begin{array}{l}\text { BEA, Gross } \\
\text { Domestic Product by Eurostat on-line } \\
\text { Stat }\end{array}$ & 2000 \\
\hline
\end{tabular}


Appendix A2. Correlation of Homicides (per million adults) with cross-country indicators from other sources

\begin{tabular}{|c|c|c|c|c|}
\hline Indicator & Unit & Source & $\begin{array}{l}\text { Number of } \\
\text { countries }\end{array}$ & $\begin{array}{l}\text { Correlation } \\
\text { coefficient }\end{array}$ \\
\hline $\begin{array}{l}\text { Governance } \\
\text { Political System }\end{array}$ & Index & $\begin{array}{l}\text { Fagerberg and } \\
\text { Srholec }(2008)\end{array}$ & 33 & $\begin{array}{l}-0.49 \\
-0.58\end{array}$ \\
\hline $\begin{array}{l}\text { Voice and Accountability } \\
\text { Political Stability and Absence of Violence/Terrorism } \\
\text { Government Effectiveness } \\
\text { Regulatory Quality } \\
\text { Rule of Law } \\
\text { Control of Corruption }\end{array}$ & Index & $\begin{array}{l}\text { Kaufmann, et al. } \\
\text { (2009) }\end{array}$ & 39 & $\begin{array}{l}-0.52 \\
-0.51 \\
-0.52 \\
-0.40 \\
-0.56 \\
-0.53\end{array}$ \\
\hline $\begin{array}{l}\text { Agreement with the statement that generally speaking most people can be } \\
\text { trusted }\end{array}$ & $\%$ & & 34 & -0.39 \\
\hline Affirmative answer on belonging to a voluntary organizations & $\%$ & & 29 & -0.60 \\
\hline Affirmative answer on doing unpaid work for a voluntary organizations & $\%$ & & 29 & -0.51 \\
\hline Affirmative answer on ever signing a petition & $\%$ & & 38 & -0.50 \\
\hline Affirmative answer on ever attending a lawful demonstration & $\%$ & & 38 & -0.38 \\
\hline $\begin{array}{l}\text { Satisfaction with the way democracy is developing in the country on a 4-point } \\
\text { scale from not at all to very much }\end{array}$ & 4-point scale & $\begin{array}{l}\text { World Value } \\
\text { Survey 1999- }\end{array}$ & 34 & -0.62 \\
\hline Confidence in the parliament on a 4-point scale from none at all to a great deal & 4-point scale & 2000 or the & 38 & -0.46 \\
\hline $\begin{array}{l}\text { Confidence in the justice system on a 4-point scale from none at all to a great } \\
\text { deal }\end{array}$ & 4-point scale & nearest & 33 & -0.45 \\
\hline $\begin{array}{l}\text { A view on how well things are going with the system for governing the } \\
\text { country on a 10-point scale from bad to good }\end{array}$ & 10-point scale & & 34 & -0.62 \\
\hline $\begin{array}{l}\text { Preparation to actually do something to improve the conditions of people in } \\
\text { the same neighborhood/community on a 5-point scale from absolutely no to } \\
\text { absolutely yes }\end{array}$ & 5-point scale & & 28 & -0.70 \\
\hline
\end{tabular}

Note: Australia, Canada, Cyprus, Iceland, Japan, Malta, New Zealand as well as the current EU candidate countries, namely Croatia, Macedonia, Serbia and Turkey, have been added to boost robustness of the comparison. All indicators, except of the indexes derived from Fagerberg and Srholec (2008) and Kaufmann, et al. (2009), are used in logs. 


\section{CIRCLE ELECTRONIC WORKING PAPERS SERIES (EWP)}

CIRCLE (Centre for Innovation, Research and Competence in the Learning Economy) is a multidisciplinary research centre set off by several faculties at Lund University and Blekinge Institute of Technology. CIRCLE has a mandate to conduct multidisciplinary research and education on the following issues: Long-term perspectives on innovation, structural change and economic growth, Entrepreneurship and venture capital formation with a special focus on new ventures, The dynamics of R\&D systems and technological systems, including their impact on entrepreneurship and growth, Regional innovation systems in different national and international contexts and International comparative analyses of national innovation systems. Special emphasis is done on innovation policies and research policies. 10 nationalities and 14 disciplines are represented among the CIRCLE staff.

The CIRCLE Electronic Working Paper Series are intended to be an instrument for early dissemination of the research undertaken by CIRCLE researchers, associates and visiting scholars and stimulate discussion and critical comment.

The working papers present research results that in whole or in part are suitable for submission to a refereed journal or to the editor of a book or have already been submitted and/or accepted for publication.

CIRCLE EWPs are available on-line at: http://www.circle.lu.se/publications

Available papers:

2011

WP 2011/01

SMEs' absorptive capacities and large firms' knowledge spillovers: Micro evidence from Mexico

Claudia de Fuentes and Gabriela Dutrénit

WP 2011/02

Comparing knowledge bases: on the organisation and geography of knowledge flows in the regional innovation system of Scania, southern Sweden

Roman Martin and Jerker Moodysson

WP 2011/03

Organizational paths of commercializing patented inventions: The effects of transaction costs, firm capabilities, and collaborative ties

Taehyun Jung and John P. Walsh

WP 2011/04

Global Innovation Networks: what are they and where can we find them? (Conceptual and Empirical issues)

Helena Barnard and Cristina Chaminade

WP 2011/05

Swedish Business R\&D and its Export Dependence Karin Bergman and Olof Ejermo 
WP 2011/06

Innovation Policy Design: Identification of Systemic Problems

Charles Edquist

WP 2011/07

Regional Institutional Environment and Its Impact on Intra-firm and Interorganisational

Innovation Networks: A Comparative Case Study in China and

Switzerland

Ju LIU

WP 2011/08

Entrepreneurship: Exploring the Knowledge Base

Hans Landström, Gouya Harirchi and Fredrik Åström

WP 2011/09

Policy coordination in systems of innovation: A structural-functional analysis of regional industry support in Sweden

Magnus Nilsson and Jerker Moodysson

WP 2011/10

Urban Design in Neighbourhood Commodification

Ana Mafalda Madureira

WP 2011/11

Technological Dynamics and Social Capability: Comparing U.S. States and European Nations

Jan Fagerberg, Maryan Feldman and Martin Srhoelec 
WP 2010/01

Innovation policies for development: towards a systemic experimentation based approach

Cristina Chaminade, Bengt-Ake Lundvall, Jan Vang-Lauridsen and KJ Joseph

WP 2010/02

From Basic Research to Innovation: Entrepreneurial Intermediaries for Research Commercialization at Swedish 'Strong Research Environments'

Fumi Kitagawa and Caroline Wigren

WP 2010/03 Different competences, different modes in the globalization of innovation?

A comparative study of the Pune and Beijing regions

Monica Plechero and Cristina Chaminade

WP 2010/04 Technological Capability Building in Informal Firms in the Agricultural

Subsistence Sector In Tanzania: Assessing the Role of Gatsby Clubs

Astrid Szogs and Kelefa Mwantima

WP 2010/05

The Swedish Paradox - Unexploited Opportunities!

Charles Edquist

WP 2010/06

A three-stage model of the Academy-Industry linking process: the perspective of both agents

Claudia De Fuentes and Gabriela Dutrénit

WP 2010/07

Innovation in symbolic industries: the geography and organisation of knowledge sourcing

Roman Martin and Jerker Moodysson

WP 2010/08

Towards a spatial perspective on sustainability transitions

Lars Coenen, Paul Benneworth and Bernhard Truffer

WP 2010/09

The Swedish national innovation system and its relevance for the emergence of global innovation networks

Cristina Chaminade, Jon Mikel Zabala and Adele Treccani

WP 2010/10

Who leads Research Productivity Change? Guidelines for R\&D policy makers

Fernando Jiménez-Sáez, Jon Mikel Zabala and José L- Zofío

WP 2010/11

Research councils facing new science and technology

Frank van der Most and Barend van der Meulen 
WP 2010/12

From new to the firm to new to the world. Effect of geographical proximity and technological capabilities on the degree of novelty in emerging economies Monica Plechero and Cristina Chaminade

WP 2010/13

Are knowledge-bases enough? A comparative study of the geography of knowledge sources in China (Great Beijing) and India (Pune)

Cristina Chaminade

WP 2010/14

Regional Innovation Policy beyond 'Best Practice': Lessons from Sweden

Roman Martin, Jerker Moodysson and Elena Zukauskaite

WP 2010/15

Innovation in cultural industries: The role of university links

Elena Zukauskaite

WP 2010/16

Use and non-use of research evaluation. A literature review

Frank van der Most

WP 2010/17

Upscaling emerging niche technologies in sustainable energy: an international comparison of policy approaches

Lars Coenen, Roald Suurs and Emma van Sandick

2009

WP 2009/01

Building systems of innovation in less developed countries: The role of intermediate organizations.

Szogs, Astrid; Cummings, Andrew and Chaminade, Cristina

WP 2009/02

The Widening and Deepening of Innovation Policy: What Conditions Provide for Effective Governance?

Borrás, Susana

WP 2009/03

Managerial learning and development in small firms: implications based on observations of managerial work

Gabrielsson, Jonas and Tell, Joakim

WP 2009/04

University professors and research commercialization: An empirical test of the "knowledge corridor" thesis

Gabrielsson, Jonas, Politis, Diamanto and Tell, Joakim

WP 2009/05

On the concept of global innovation networks

Chaminade, Cristina

WP 2009/06 
Technological Waves and Economic Growth - Sweden in an International Perspective 1850-2005

Schön, Lennart

WP 2009/07

Public Procurement of Innovation Diffusion: Exploring the Role of Institutions and Institutional Coordination

Rolfstam, Max; Phillips, Wendy and Bakker, Elmer

WP 2009/08

Local niche experimentation in energy transitions: a theoretical and empirical exploration of proximity advantages and disadvantages

Lars Coenen, Rob Raven, Geert Verbong

WP 2009/9

Product Development Decisions: An empirical approach to Krishnan and Ulrich Jon Mikel Zabala, Tina Hannemann

WP 2009/10

Dynamics of a Technological Innovator Network and its impact on technological performance

Ju Liu, Cristina Chaminade

WP 2009/11

The Role of Local Universities in Improving Traditional SMEs Innovative Performances: The Veneto Region Case

Monica Plechero

WP 2009/12

Comparing systems approaches to innovation and technological change for sustainable and competitive economies: an explorative study into conceptual commonalities, differences and complementarities

Coenen, Lars and Díaz López, Fernando J.

WP 2009/13

Public Procurement for Innovation (PPI) - a Pilot Study

Charles Edquist

WP 2009/14

Outputs of innovation systems: a European perspective

Charles Edquist and Jon Mikel Zabala

2008

WP 2008/01

R\&D and financial systems: the determinants of R\&D expenditures in the Swedish pharmaceutical industry

Malmberg, Claes

WP 2008/02

The Development of a New Swedish Innovation Policy. A Historical Institutional Approach

Persson, Bo 
WP 2008/03

The Effects of R\&D on Regional Invention and Innovation

Olof Ejermo and Urban Gråsjö

WP 2008/04

Clusters in Time and Space: Understanding the Growth and Transformation of Life Science in Scania

Moodysson, Jerker; Nilsson, Magnus; Svensson Henning, Martin

WP 2008/05

Building absorptive capacity in less developed countries

The case of Tanzania

Szogs, Astrid; Chaminade, Cristina and Azatyan, Ruzana

WP 2008/06

Design of Innovation Policy through Diagnostic Analysis:

Identification of Systemic Problems (or Failures)

Edquist, Charles

WP 2008/07

The Swedish Paradox arises in Fast-Growing Sectors

Ejermo, Olof; Kander, Astrid and Svensson Henning, Martin

WP 2008/08

Policy Reforms, New University-Industry Links and Implications for Regional Development in Japan

Kitagawa, Fumi

WP 2008/09

The Challenges of Globalisation: Strategic Choices for Innovation Policy

Borrás, Susana; Chaminade, Cristina and Edquist, Charles

WP 2008/10

Comparing national systems of innovation in Asia and Europe: theory and comparative framework

Edquist, Charles and Hommen, Leif

WP 2008/11

Putting Constructed Regional Advantage into Swedish Practice? The case of the VINNVÄXT initiative 'Food Innovation at Interfaces'

Coenen, Lars; Moodysson, Jerker

WP 2008/12

Energy transitions in Europe: 1600-2000

Kander, Astrid; Malanima, Paolo and Warde, Paul

WP 2008/13

RIS and Developing Countries: Linking firm technological capabilities to regional systems of innovation

Padilla, Ramon; Vang, Jan and Chaminade, Cristina 
WP 2008/14

The paradox of high R\&D input and low innovation output: Sweden

Bitarre, Pierre; Edquist, Charles; Hommen, Leif and Ricke, Annika

WP 2008/15

Two Sides of the Same Coin? Local and Global Knowledge Flows in Medicon Valley

Moodysson, Jerker; Coenen, Lars and Asheim, Bjørn

WP 2008/16

Electrification and energy productivity

Enflo, Kerstin; Kander, Astrid and Schön, Lennart

WP 2008/17

Concluding Chapter: Globalisation and Innovation Policy

Hommen, Leif and Edquist, Charles

WP 2008/18

Regional innovation systems and the global location of innovation activities: Lessons from China

Yun-Chung, Chen; Vang, Jan and Chaminade, Cristina

WP 2008/19

The Role of mediator organisations in the making of innovation systems in least developed countries. Evidence from Tanzania

Szogs, Astrid

WP 2008/20

Globalisation of Knowledge Production and Regional Innovation Policy:

Supporting Specialized Hubs in the Bangalore Software Industry

Chaminade, Cristina and Vang, Jan

WP 2008/21

Upgrading in Asian clusters: Rethinking the importance of interactive-learning Chaminade, Cristina and Vang, Jan

2007

WP 2007/01

Path-following or Leapfrogging in Catching-up: the Case of Chinese Telecommunication Equipment Industry

Liu, Xielin

WP 2007/02

The effects of institutional change on innovation and productivity growth in the Swedish pharmaceutical industry

Malmberg, Claes

WP 2007/03

Global-local linkages, Spillovers and Cultural Clusters: Theoretical and Empirical insights from an exploratory study of Toronto's Film Cluster

Vang, Jan; Chaminade, Cristina 
WP 2007/04

Learning from the Bangalore Experience: The Role of Universities in an Emerging Regional Innovation System

Vang, Jan; Chaminade, Cristina.; Coenen, Lars.

WP 2007/05

Industrial dynamics and innovative pressure on energy -Sweden with European and Global outlooks

Schön, Lennart; Kander, Astrid.

WP 2007/06

In defence of electricity as a general purpose technology

Kander, Astrid; Enflo, Kerstin; Schön, Lennart

WP 2007/07

Swedish business research productivity - improvements against international trends

Ejermo, Olof; Kander, Astrid

WP 2007/08

Regional innovation measured by patent data - does quality matter?

Ejermo, Olof

WP 2007/09

Innovation System Policies in Less Successful Developing countries: The case of Thailand

Intarakumnerd, Patarapong; Chaminade, Cristina

2006

WP 2006/01

The Swedish Paradox

Ejermo, Olof; Kander, Astrid

WP 2006/02

Building RIS in Developing Countries: Policy Lessons from Bangalore, India

Vang, Jan; Chaminade, Cristina

WP 2006/03

Innovation Policy for Asian SMEs: Exploring cluster differences

Chaminade, Cristina; Vang, Jan.

WP 2006/04

Rationales for public intervention from a system of innovation approach: the case of VINNOVA.

Chaminade, Cristina; Edquist, Charles

WP 2006/05

Technology and Trade: an analysis of technology specialization and export flows

Andersson, Martin; Ejermo, Olof 
WP 2006/06

A Knowledge-based Categorization of Research-based Spin-off Creation

Gabrielsson, Jonas; Landström, Hans; Brunsnes, E. Thomas

WP 2006/07

Board control and corporate innovation: an empirical study of small technology-based firms

Gabrielsson, Jonas; Politis, Diamanto

WP 2006/08

On and Off the Beaten Path:

Transferring Knowledge through Formal and Informal Networks

Rick Aalbers; Otto Koppius; Wilfred Dolfsma

WP 2006/09

Trends in R\&D, innovation and productivity in Sweden 1985-2002

Ejermo, Olof; Kander, Astrid

WP 2006/10

Development Blocks and the Second Industrial Revolution, Sweden 1900-1974

Enflo, Kerstin; Kander, Astrid; Schön, Lennart

WP 2006/11

The uneven and selective nature of cluster knowledge networks: evidence from the wine industry

Giuliani, Elisa

WP 2006/12

Informal investors and value added: The contribution of investors' experientially acquired resources in the entrepreneurial process

Politis, Diamanto; Gabrielsson, Jonas

WP 2006/13

Informal investors and value added: What do we know and where do we go?

Politis, Diamanto; Gabrielsson, Jonas

WP 2006/14

Inventive and innovative activity over time and geographical space: the case of Sweden

Ejermo, Olof

2005

WP 2005/1

Constructing Regional Advantage at the Northern Edge

Coenen, Lars; Asheim, Bjørn

WP 2005/02

From Theory to Practice: The Use of the Systems of Innovation Approach for Innovation Policy

Chaminade, Cristina; Edquist, Charles

WP 2005/03

The Role of Regional Innovation Systems in a Globalising Economy: Comparing Knowledge Bases and Institutional Frameworks in Nordic Clusters 
Asheim, Bjørn; Coenen, Lars

WP 2005/04

How does Accessibility to Knowledge Sources Affect the Innovativeness of Corporations? Evidence from Sweden

Andersson, Martin; Ejermo, Olof

WP 2005/05

Contextualizing Regional Innovation Systems in a Globalizing Learning Economy: On Knowledge Bases and Institutional Frameworks

Asheim, Bjørn; Coenen, Lars

WP 2005/06

Innovation Policies for Asian SMEs: An Innovation Systems Perspective

Chaminade, Cristina; Vang, Jan

WP 2005/07

Re-norming the Science-Society Relation

Jacob, Merle

WP 2005/08

Corporate innovation and competitive environment

Huse, Morten; Neubaum, Donald O.; Gabrielsson, Jonas

WP 2005/09

Knowledge and accountability: Outside directors' contribution in the corporate value chain

Huse, Morten, Gabrielsson, Jonas; Minichilli, Alessandro

WP 2005/10

Rethinking the Spatial Organization of Creative Industries

Vang, Jan

WP 2005/11

Interregional Inventor Networks as Studied by Patent Co-inventorships

Ejermo, Olof; Karlsson, Charlie

WP 2005/12

Knowledge Bases and Spatial Patterns of Collaboration: Comparing the Pharma and Agro-Food Bioregions Scania and Saskatoon

Coenen, Lars; Moodysson, Jerker; Ryan, Camille; Asheim, Bjørn; Phillips, Peter

WP 2005/13

Regional Innovation System Policy: a Knowledge-based Approach

Asheim, Bjørn; Coenen, Lars; Moodysson, Jerker; Vang, Jan

WP 2005/14

Face-to-Face, Buzz and Knowledge Bases: Socio-spatial implications for learning and innovation policy

Asheim, Bjørn; Coenen, Lars, Vang, Jan

WP 2005/15

The Creative Class and Regional Growth: Towards a Knowledge Based Approach

Kalsø Hansen, Høgni; Vang, Jan; Bjørn T. Asheim 
WP 2005/16

Emergence and Growth of Mjärdevi Science Park in Linköping, Sweden Hommen, Leif; Doloreux, David; Larsson, Emma

WP 2005/17

Trademark Statistics as Innovation Indicators? - A Micro Study Malmberg, Claes 